\title{
RUI BARBOSA E FACEBOOK: ENTRE DOIS CAMINHOS
}

Havia na França, em meados do século XIX, uma região afetada por permanente alagamento, cujas ruas só se conseguia atravessar com auxílio de pernas de pau, de mais de metro de altura. Alguns dizem, inclusive, que decorre daí o surgimento do famoso utensílio circense. Verdadeiro ou não esse registro histórico, o fato é que o Brasil moral de hoje parece estar como esses locais.

A assertiva acima pertence a Rui Barbosa, ${ }^{3}$ e foi escrito no início do século passado. Entretanto, mantém tão forte atualidade que parece ter sido publicado recentemente em uma página do Facebook.

Minha preocupação com o presente capítulo não é trazer um modo inovador que permita atravessar o alagamento sem se molhar, mas buscar a origem do vazamento, para, de forma clara, podermos pensar acerca das soluções. Num ambiente tão instável, falar em futuro é uma aventura perigosa e pouco produtiva; mais apropriado é retomar o processo e compreender melhor o passado a fim de superá-lo.

Dedico esta parte desta obra para propor uma reflexão sobre as razões, os "porquês", do ponto de vista do controle, que nos levaram a um cenário tão dramático de corrupção e destruição fiscal, para que, olhando no retrovisor, possamos desenhar o roteiro desse caminho perdido.

Desde logo, é preciso deixar claro: o Brasil não vive uma crise, mas uma combinação de crises simultâneas e interconectadas entre si.

3 BARBOSA, Rui. A crise moral. Rio de Janeiro: Organizações Simões, 1932, p. 102. 
Primeiro, uma crise política, marcada pela falência do sistema de representatividade política, onde já não mais existe uma relação de confiança entre os eleitores e os eleitos. Fala-se, portanto, na crise de legitimidade política e na "era da desconfiança”. Os partidos políticos, que surgiram com o escopo de funcionar como porta-vozes das reivindicações populares e com a tintura ideológica da sociedade, hoje, tornaram-se verdadeiros balcões de negócios escusos inseridos em um grande mercado chamado Congresso Nacional, cuja moeda em circulação são as emendas parlamentares, as comissóes parlamentares de inquérito e a conversão de medidas provisórias. Algo como uma "democracia com fins lucrativos", na qual se proliferam os partidos não pelo aumento dos ideais na sociedade, mas pela ânsia em captar e desviar recursos públicos. Essa conjuntura acaba incentivando formas obscuras e inconfessadas de ajuste entre o Parlamento e o Poder Executivo, para que este último consiga aprovar seus projetos e governar com tranquilidade. Com isso, abre-se um campo fértil para a corrupção, especialmente através da troca de favores e cargos.

Segundo, uma crise econômico-fiscal, refletida no orçamento geral da União para 2018, com previsão de que as despesas serão maiores do que as receitas em R\$ 157 bilhôes, ${ }^{4}$ evidenciando a insolvência do Estado e, sobretudo, a culminância de um longo período de irresponsabilidade fiscal e desmazelo pelas regras de finanças públicas. Mesmo após a promulgação da Lei Complementar n. 101/2000 (Lei de Responsabilidade Fiscal), relevante marco institucional para o alcance do equilíbrio fiscal, a União, os estados e municípios persistiram gastando mais do que a sua capacidade financeira, e se endividando a despeito das metas estabelecidas. O resultado não poderia ser outro senão uma dívida pública bruta de $\mathrm{R} \$ 4,4$ trilhões (70,5\% do PIB), ${ }^{5}$ que em poucos anos pode alcançar $100 \%$ do PIB; a ruinosa situação econômica dos estados e municípios brasileiros; a superinflação e o recorde histórico de desempregados. Prometeu-se aquilo que não se tinha, hipotecando o futuro para pagar o presente. E, assim, cada vez mais os cidadãos-contribuintes e usuários de serviços públicos vão percebendo que os altos tributos pagos não têm contrapartida compatível com a qualidade dos serviços prestados pelo Estado.

4 Projeto de Lei do Congresso Nacional n. 20, de 2017: estima a receita e fixa a despesa da União para o exercício de 2018. Disponível em: <http://www.congressonacional.leg.br/materias/pesquisa/-/materia/130650>. Acesso em: 7 dez. 2017.

5 SIMÃO, Edna. Dívida bruta do governo vai a 70,5\% do PIB. Valor Econômico. Disponível em: <http://www.valor.com.br/brasil/4819052/divida-bruta-do-governo-vai-705-do-pib>. Acesso em: 27 dez. 2016. 
Finalmente, uma crise de valores, que tem a ver com a estarrecedora extensão do fenômeno da corrupção no país e com a tradição patrimonialista que possui raízes profundas estabelecidas desde o período colonial, tomando conta das relações entre o setor público e o privado. A sociedade brasileira, vítima desse desvirtuamento de valores éticos, assiste escandalizada aos inúmeros episódios de desvios com os recursos coletivos, praticados em todos os poderes e níveis de governo, e repetidos diariamente.

Desta forma, ao alterar a alocação de recursos orçamentários em favor de benefícios próprios (alocação particularista), diminuir a eficiência do setor público e desviar recursos dos contribuintes do seu destino público, a corrupção reduz os direitos do povo. Alguns minutos de audição do noticiário são suficientes para concluir que a administração pública está contaminada pelo pior dos parasitas. A corrupção se apropria de cargos e funções estatais visando à troca de favores e promove o saque dos cofres públicos com o fim de perpetuar-se no poder. É no mínimo alarmante que sejamos o país que mais perdeu posições no índice de percepção da corrupção elaborado pela Organização Transparência Internacional, sediada em Berlim, saindo da 69a , em 2014, para a 96a colocação, em 2017, dos 168 países avaliados. ${ }^{6}$

Não se pode dizer que essas sejam crises independentes, que ocorreram de forma autônoma e por fatores diversos. Representam, as três dimensões, o agravamento de um ciclo-vicioso, na medida em que, quanto mais intensa for a crise de valores, maior será a decadência político-econômica o que, por sua vez, dá mais combustível às práticas de corrupção. Embora seja difícil estabelecer uma relação de causalidade direta, até os mais céticos devem concordar que existe uma sintonia fina entre a deterioração fiscal, a falta de decência política e a corrupção.

Nesse cenário cercado de desconfiança, a única certeza que parece mantida é a de que novos escândalos serão descobertos, novos valores serão somados à conta já enorme - dos prejuízos ao patrimônio público e que novos empresários, autoridades políticas e operadores serão presos na operação de nome estranho da manhã seguinte.

E assim segue o país, inserto em um ciclo de aceitação social do inaceitável, como se acontecimentos graves e vergonhosos como estes passassem a integrar a sua rotina e, assim, esculpissem outro padrão de normalidade.

Agora vamos às possíveis causas.

6 Corruption Perception Index (CPI) 2017. Transparency international. Disponível em: <http:// www.transparency.org/cpi2017>. Acesso em: 24 jan. 2017. 
Para não incorrer em apelos intuitivos, nem em argumentos vazios, é preciso delimitar a questão. Dar conta de todas as razões dessa crise multifacetada seria impossível ou, se possível, certamente cobraria mais do que um livro ou dois, mas uma coletânea inteira de obras. Não é o que proponho.

Quero abordar, neste fragmento inicial, as causas que, do ponto de vista do controle, sobretudo do controle externo, no qual atuo e estudo há mais de vinte anos, entendo que teriam contribuído, decisivamente, para o atingimento desse quadro desanimador que foi pintado acima.

A propósito, cabe ressaltar que não é a intenção tratar da corrupção e das questôes fiscais como fenômenos puramente teóricos, abstratos e que pareçam distantes da realidade, mas abordá-los como problemas práticos que são, e a forma como os seus efeitos repercutem forte e cotidianamente na vida de todos. Seja pela obra paralisada há anos, que impede a geração de empregos e a prestação do serviço público a que serviria; seja pelo remédio que não chega a tempo às prateleiras do Sistema Único de Saúde (SUS); seja pelo superfaturamento no contrato de merenda escolar, cujo adicional custeou viagens ao exterior e jantares em restaurantes luxuosos. Essas são consequências reais, de problemas reais, cujos motivos quero expor-lhes agora.

Para facilitar a compreensão, proponho uma análise dívida em três grandes eixos que constituem as causas genéricas: a) irrealismo orçamentário e falta de planejamento no curso de ações políticas; b) deficiência no engajamento cívico; c) impunidade como indutora de condutas reprováveis. Destas três razões principais, emanam circunstâncias específicas que ajudam a compreender como cada uma colabora com a crise política-econômica-ética vivenciada atualmente.

É importante explicar, também, porque considero que estas sejam as causas mais relevantes e a forma pela qual as aponto de modo genérico e em blocos separados. A justificativa é simples: cada uma delas fere um princípio essencial do Estado Democrático de Direito.

O irrealismo orçamentário ofende, gravemente, o princípio da transparência, que é fundamental na existência e funcionamento de qualquer democracia, consolidada ou não, como instrumento do exercício da cidadania no controle do gasto público. Ao esconder resultados, maquiar e pedalar despesas, simular receitas, ocultar demonstrativos e endividamentos, com o único propósito de escapar à fiscalização dos órgãos de controle e da sociedade, os governantes quebram o vínculo básico de confiança estabelecido com os cidadãos nas urnas e, portanto, perdem parte da legitimidade que lhes foi conferida. Democracia pressupóe, acima de qualquer realidade, uma transparente responsabilidade do Estado e, em especial, do 
governo, de modo que a gestão não pode ser feita em esconderijos capazes de impedir o controle social quanto ao emprego das verbas públicas. Não se pode perder de vista a importância do orçamento para a concretização dos direitos fundamentais. Quando a previsão de receitas e fixação das despesas que irão custear esses direitos é opaca, maior espaço sobra para dissimular os números, o que, indiretamente, resulta em um maior nível de corrupção. Tanto mais visível seja o orçamento, maior a probabilidade de que a irresponsabilidade fiscal seja fiscalizada e, assim, prevenida.

A deficiência no engajamento cívico, por sua vez, atinge o pilar de sustentação do edifício democrático, que é a autodeterminação dos cidadãos e o direito que lhes cabe de decidir sobre todas as questôes que sejam de seu interesse. Se a sociedade não tiver os meios de se autogovernar, as políticas, sejam as mais bem-intencionadas, podem ser ineficazes ou corromper-se em sua implementação. ${ }^{7}$ Além do mais, sem a inserção do povo no debate, as políticas nascem órfãs de legitimidade. O filósofo Rousseau foi exato ao afirmar que ou a democracia é participativa, ou é uma farsa. Ao analisar o sistema político inglês, ele constata que "o povo inglês pensa ser livre. Ele se engana enormemente. Ele é livre apenas durante a eleição dos membros do Parlamento. Tão logo eles são eleitos, o povo inglês é um escravo". ${ }^{8}$ Neste ponto, percebe-se problemas tanto nos inputs como nos outputs para a participação, ou seja, as duas margens do rio estão afetadas, tanto pela falta de incentivos do poder público à gestão compartilhada, quanto pelo ainda intenso nível de desinteresse cívico da população em colocar as suas digitais nos projetos políticos.

Por fim, a impunidade, uma das piores reminiscências aristocráticas que persiste em nos envergonhar, constitui a violação mais clara ao princípio da igualdade, cuja essência remete à lição básica da república segundo a qual todos estão sujeitos à lei, ao império do direito e que, portanto, não deve haver discriminações nem privilégios injustificados. É completamente inverso aos valores democráticos que alguém, pelo poder político que possui ou pela fortuna que ostenta, se beneficie desses fatores para escapar da sanção pelos ilícitos que cometeu. Além do mais, a impunidade por si só é um fator de corrupção, pois estimula um ciclo vicioso, no qual a percepção de que não haverá resposta ao delito, incentiva a reincidência e aumenta a sensação geral de que o crime realmente compensa.

7 CASTELLS, Manuel. Redes de indignação e esperança. Movimentos sociais na era da internet. Tradução de Carlos Alberto Medeiros. Rio de Janeiro: Zahar, 2013, p. 13.

8 ROUSSEAU, Jean-Jacques. O contrato social. Livro 3, cap. 15, 1978, p. 102. 
Delineadas estas premissas, passo a analisar em tópicos específicos cada um desses blocos e as suas implicações. Antes, gostaria de fazer uma ressalva: Se algum tema lhe parecer de difícil compreensão, não se preocupe! Decifrar o caos no qual se encontra o Brasil é um desafio que, às vezes, nem mesmo especialistas conseguem empreender. O propósito desta publicação é justamente (tentar) simplificar essas questôes, a fim de encurtar a distância do leigo aos problemas do país e propor algumas soluçōes. É um trabalho árduo, eu sei, todavia, na linha do que disse Lao Tsé: "uma viagem de mil léguas começa com o primeiro passo", então vamos lá!

\section{Primeiro eixo: irrealismo orçamentário e falta de planejamento}

Nada revela de forma mais clara o caráter de uma sociedade do que a política fiscal empregada pelo seu setor público. ${ }^{9}$ A forma com que se utiliza o dinheiro do povo dá cara e corporifica a intensão de um governo.

Em "O Mercador de Veneza”, de William Shakespeare, a personagem e heroína da história, Pórcia, é rica e titular de uma farta herança. Bonita, acabou despertando o interesse e a paixão de muitos homens. Desejando casar-se, propôs um desafio àqueles que pretendiam conquistá-la. Três cofres estariam dispostos em um quarto: um de ouro, outro de prata e o último, de bronze. Destes, apenas um continha um retrato de Pórcia. Se fosse este o escolhido, o casamento estaria ali mesmo selado, mas se acaso errassem, os pretendentes teriam de partir imediatamente.

Motivados pela beleza da jovem senhorita e adotando como critério para a escolha o valor dos cofres, os dois primeiros candidatos, príncipes de Marrocos e Aragão, elegeram, respectivamente, os cofres de ouro e prata. Erraram, ambos. Finalmente, o veneziano Bassânio arriscou a sorte, e antes de escolher o mais barato dos cofres, que mais tarde se mostraria ser o correto, justificou a sua decisão: "Bastantes vezes a aparência externa carece de valor. Sempre enganado tem sido o mundo pelos ornamentos. Em direito, que causa tão corrupta e estragada, não fica apresentável por uma voz graciosa, que aparência malévola disfarça?”. ${ }^{10}$

Voltando os olhos à atualidade, especialmente à forma como o orçamento brasileiro tem se revelado fictício, a percepção de Bassânio parece adequar-se perfeitamente à realidade financeira do país.

\footnotetext{
9 SCHUMPETER, Joseph A. História da análise econômica. Rio de Janeiro: Fundo de Cultura, 1964, p. 33.

10 SHAKESPEARE, William. O mercador de Veneza. Almada: Água-forte, 2002.
} 
$\mathrm{Na}$ tradição britânica, berço da noção de controle dos gastos do estado, o orçamento público anual é anunciado pelo Primeiro-ministro na porta de sua residência, em uma coletiva de imprensa convocada exclusivamente para este fim e que mais se assemelha à revelação bombástica de alguma celebridade de Hollywood. Nos meses posteriores, a peça orçamentária é objeto de severas discussões pela imprensa e pela sociedade, ocupando o centro dos debates públicos. Não é o nosso caso. Por aqui, o orçamento público é elaborado no escaninho de gabinetes fechados dos Ministérios e Secretarias, passa desapercebido às emendas impositivas dos parlamentares para suas bases eleitorais e vem à tona sem que a maioria dos brasileiros sequer note. Assim, a forma como serão aplicados os recursos que saem do bolso do contribuinte para o Estado, fica, na maioria das vezes, subentendido; oculto. Esse hábito lastimável de descaso pelo processo orçamentário é uma das heranças da colonização ibérica que ainda ressoam no Brasil. Em um parecer de 1905 sobre o Código da Contabilidade Pública, publicado no Jornal do Commercio, já se dizia que "balanços e orçamentos permanecem para a grande massa dos contribuintes, para a imprensa e para a maior parte do parlamento numa região sombria, mysteriosa e cheia de sorprezas (sic)". ${ }^{11}$

É na linha desse trem-fantasma dos gastos não revelados que nós nos deparamos, atualmente, atingidos pelo esgotamento da capacidade estatal em prover os serviços públicos e saldar as suas dívidas. As péssimas condições econômicas hoje enfrentadas são reflexo desse irrealismo com que se faz e executa o orçamento público, e da falta de planejamento orçamentário.

Não que o Brasil não tenha experimentado avanços em termos de higidez financeira e estabilidade fiscal. Pelo contrário, a promulgação da Lei Complementar n. 101, em 4 de maio de 2000, denominada Lei de Responsabilidade Fiscal, ao pautar-se pelos deveres de transparência e planejamento, estabelecendo limites e metas de resultado, representou um dos mais relevantes marcos na construção do equilíbrio nas contas públicas, até então marcadas pela inflação galopante e pela desorganização completa. Cerca dos dezoito anos de vigência e sendo parâmetro internacional em termos de normas sobre política fiscal, é inegável o papel que a LRF desempenhou, e ainda desempenha, na consolidação das instituiçõoes fiscais brasileiras.

Apesar disso, como em tantas outras searas no Brasil, a lei por si só não foi suficiente para incutir comportamentos responsáveis e impedir que retrocessos,

11 DAVID CAMPISTA, apud VEIGA FILHO, João Pedro da. Manual da sciencia das finanças. 2. ed. 1906, p. 43, nota de rodapé n. 2. 
voltados à expansão descontrolada dos gastos e à concessão desordenada de privilégios fiscais, fossem levados a cabo. O dever de observar metas, divorciado do compromisso das autoridades em controlar as despesas, fez com que os governos recorressem constantemente a formas heterodoxas pouco transparentes de contabilização, batizadas sob o eufemismo de Contabilidade Criativa.

Ainda que no transcurso de 2015 a 2016, tenha-se percebido uma incipiente consciência orçamentária e uma maior preocupação dos cidadãos sobre as contas públicas, muito em virtude da sucessão de desmandos financeiros, a falta de transparência ainda constitui uma marca dominante nos orçamentos brasileiros. É um péssimo hábito do qual os governantes dificilmente abdicarão, haja vista já ter lhes mostrado render grande número de votos.

Precisamos conversar, portanto, sobre essa tal contabilidade criativa, que sorrateiramente fez desmoronar a saúde orçamentário-financeira do país.

Decerto, a contabilidade pública de um país cuja extensão supera todo o continente europeu e a receita é considerável (em 2017 o orçamento da União ultrapassou 3 trilhões e 500 bilhões de reais), não é algo banal. Longe disso, revela-se uma atividade extremamente complicada. Para montar esse imenso quebra-cabeça orçamentário que irá dispor sobre todas as ações governamentais e políticas públicas que irão se desenvolver em determinado ano, são indispensáveis técnicas complexas e agentes especializados. Deste modo, quanto mais transparente e rigorosa for a organização das contas, mais confiáveis elas serão, permitindo investimentos e crescimento econômico. ${ }^{12}$

Como, então, explicar o surgimento de práticas que são tão danosas às contas públicas como as de criatividade contábil?

A imprecisão dos números, afirmam John Micklethawait e Adrian Wooldridge, é uma maldição do setor público, e quando os países enfrentam problemas, os números fogem ainda mais ao controle. ${ }^{13}$

Após um longo período marcado pela frouxidão das finanças do Estado brasileiro, da hiperinflação e dos juros altos, tornou-se premente a necessidade de criar regras que impusessem o dever de responsabilidade na gestão do dinheiro público, através de restrições e limites, de modo a permitir o equilíbrio entre receitas e despesas. Diante dessa necessidade, seguindo tardiamente um padrão mundial

12 CONTI, José Maurício. Levando o direito financeiro a sério. São Paulo: Blucher, 2016, p. 39.

13 MICKLETHAWAIT, John; WOOLDRIDGE, Adrian. A quarta revolução: a corrida global para reinventar o estado. Tradução de Afonso Celso da Cunha Serra. Ed. Portfolio-Penguin, 2015, p. 88. 
de recrudescimento das regras sobre finanças públicas, que o Brasil teve editada a Lei de Responsabilidade Fiscal, regulamentando, após doze anos, o art. 163, da $\mathrm{CRFB} / 88$.

A LRF trouxe maior rigor às contas estabelecendo limites para gastos e para o endividamento público, restrições à realização de transferências incompatíveis com as metas de resultado fiscal, além de outras formas de contenção. Isso tudo fez com que se elevasse a importância de uma contabilidade pública cada vez mais clara e cuidadosa.

No entanto, também na linha da experiência observada em outros países que adotaram instrumentos semelhantes de controle fiscal, a imposição de regras mais rígidas às finanças públicas converteu-se em incentivo à utilização de medidas contábeis não transparentes, com o propósito de escapar das suas disposições. ${ }^{14}$ Desta forma, seria possível promover alocações particularistas, expandindo descoordenadamente os gastos e o endividamento público, sem que isso implicasse mostrar números desfavoráveis no balanço, escapando do revés político e das sanções jurídicas.

O tiro saiu pela culatra, pois, conquanto a imposição de limites e restrições fiscais objetivasse reduzir a imprudência do governo do manejo das contas públicas, induziu comportamentos oportunistas de políticos em busca de resultados imediatos e ganhos eleitorais. Distorcendo dados e flexibilizando interpretações da lei, esses agentes promovem a total inversão da finalidade da norma: ao invés de os comportamentos se adequarem à LRF, faz-se com que a LRF se adeque aos comportamentos, de modo que a lei sirva de anteparo para práticas imprudentes e desonestas, às custas do povo.

O ponto que deve ser ressaltado é que tais condutas prejudicam o controle das finanças públicas, fragilizando a qualidade do gasto governamental e potencializando oportunidades para o clientelismo e a patronagem. Sem um controle financeiro eficaz, o orçamento deixa de ser utilizado para funções públicas essenciais, como a distribuição de renda, o aprimoramento da eficiência administrativa, a elaboração de programas governamentais sustentáveis, e passa a financiar a corrupção generalizadas das contas, que pode ocorrer tanto pelo desvio direto de recursos, pela simulação de resultados a partir de números escorregadios. Como dirigir eficaz e honestamente uma entidade complexa quando não se confia nos números?

14 Conforme identifica Kopits, a evolução das regras de política fiscal, por meio de previsões constitucionais e legais, teve início há mais de um século e meio. (KOPITS, George. Fiscal rules: useful policy framework or unnecessary ornament. IMF Working Paper, 2001, p. 3.) 
-• Finanças públicas: travessia entre o passado e o futuro

Como afirmado, anteriormente, essa tendência à contabilidade criativa não ocorreu somente no Brasil. A preocupação quanto ao incremento dessa prática se fez presente em vários países europeus, especialmente frente a limitação do déficit estabelecido pelo tratado de Maastricht. ${ }^{15}$

Alguns casos foram emblemáticos. A Grécia reagiu à crise financeira utilizando um sistema de swaps confidencial, concebido pelo Goldman Sachs, para manipular o índice da dívida pública em relação ao Produto Interno Bruto. ${ }^{16}$ Mais recentemente, na província chinesa de Liaoning, autoridades admitiram a perpetração de falsificações fiscais com o intuito de inflar as receitas públicas, que aumentaram artificialmente ao menos $20 \%$ no período entre 2011 e $2014 .{ }^{17}$

Merece destaque o caso ocorrido na França, onde o método utilizado para distorcer os dados foi encontrado nas contas de governo da Presidente Dilma Rousseff, de 2014, denominado pedaladas fiscais. Lá, conseguiu-se reduzir o déficit orçamentário do exercício de 1997 graças a um pagamento feito pela empresa pública France Telécom de despesas cuja responsabilidade cabia ao Estado. A contabilização deste pagamento se deu, contudo, como um "recibo de capital", e não como "transação de ativos" (operação de crédito), que seria o correto, contando, desta forma, na redução do déficit, interferindo no cálculo e permitindo números mais suaves no resultado final das contas.

Se não é algo exclusivamente brasileiro, tampouco constitui um expediente recente. Michael J. Jones aponta que fraudes envolvendo a contabilização de recursos públicos eram comuns em Atenas do século $\mathrm{V}$, e a sua prevenção é uma das razões pelas quais Zenon, Ministro das Finanças de Ptolomeu II, faraó egípcio, passou a manter registros de documentos contábeis. ${ }^{18}$

No Brasil, o surgimento da criatividade nas contas públicas pode ser remetida ao ano de 2009, quando começaram a surgir notícias de que o governo estava abatendo gastos das metas de resultado primário para melhorar o saldo final das

15 MILESI-FERRETTI, Gian Maria. Good, Bad or Ugly? On the effects of fiscal rules with creative accounting. FMI Working Paper, 2000, p. 3.

16 MICKLETHAWAIT, John; WOOLDRIDGE, Adrian. A quarta revolução: a corrida global para reinventar o estado. Tradução de Afonso Celso da Cunha Serra. Ed. Portfolio-Penguin, 2015 , p. 88.

17 HANCOCK, Tom. China province admits falsifying fiscal data. Financial Times. Disponível em: <https://www.ft.com/content/b25d1b32-dd37-11e6-9d7c-be108f1c1dce>. Acesso em: 18 jan. 2017.

18 JONES, Michael. Creative accounting, fraud and international accounting scandals. England: Wiley, 2011, p. 22. 
contas. ${ }^{19}$ Outros descontos semelhantes foram surgindo, como o dos chamados gastos tributários, representados pelos benefícios tributários concedidos de forma pouco transparente pelo governo federal..$^{20}$ Tais práticas se tornaram habituais com o passar do tempo e atingiram o ápice em 2014, quando o Poder Executivo da União, para conseguir fechar as contas e atender, mesmo que artificialmente, as regras da LRF, alterou a meta de resultado primário inicialmente fixada pela Lei de Diretrizes Orçamentárias (LDO), permitindo o desconto integral dos gastos no PAC e de desonerações de tributos aplicadas em diversos setores, da meta de superávit. ${ }^{21}$ Aquele ano terminou marcado por um déficit primário histórico de 0,6\% do PIB, sem contar o efeito negativo das pedaladas fiscais efetivadas durante o exercício.

Já em 2010, o periódico inglês Financial Times publicara um editorial reportando que só havia sido possível ao governo brasileiro saldar as contas de 2009, apresentando um resultado primário positivo, graças à contabilidade criativa, que chamou de jeitinho monetário brasileiro. ${ }^{22}$ Mais tarde, em janeiro de 2013, outra revista britânica, o The Economist, informou acerca da utilização do que chamou de números errados, pelo governo brasileiro, para conseguir atingir o equilíbrio fiscal no final do exercício e conter a inflação. ${ }^{23}$

Essas reportagens, e tantas outras publicadas em território brasileiro, já davam conta de que tais práticas poderiam conduzir, como mais tarde levaram, a economia brasileira à completa desordem.

No entanto, a resistência dos governantes em abrir mão das políticas de curto-prazo, em prol do equilíbrio fiscal, encontrou nos expedientes opacos e maliciosos

19 NÓBREGA, Mailson; SALTO, Felipe. Contabilidade criativa turva meta fiscal. Estado de S.Paulo, 30 de novembro de 2009. Disponível em: <http:/www.estadao.com.br/noticias/ geral,contabilidade-criativa-turva-meta-fiscal,474130 >. Acesso em: 23 nov. 2016.

20 SALTO, Felipe; ALMEIDA, Mansueto. Finanças públicas: da contabilidade criativa ao resgate da credibilidade. 2. ed. Rio de Janeiro: Record, 2016.

21 Projeto de Lei n. 36, de 2014: "Altera a Lei n. 12.919, de 24 de dezembro de 2013, que dispõe sobre as diretrizes para a elaboração e execução da Lei Orçamentária de 2014". Art. 3º A meta de superávit a que se refere o art. $2^{\circ}$ poderá ser reduzida no montante das desoneraçóes de tributos e dos gastos relativos ao Programa de Aceleração do Crescimento - PAC, cujas programaçōes serão identificadas no Projeto e na Lei Orçamentária de 2014 com identificador de Resultado Primário previsto na alínea "c" do inciso II do $\$ 4^{\circ}$ do art. $7^{\circ}$ desta Lei.

22 Brazil's monetary jeitinho. Financial Times. Disponível em: <http://blogs.ft.com/beyond-brics/2013/01/15/brazils-monetary-jeitinho/>. Acesso em: 21 out. 2016.

23 Wrong numbers: more inflation, less growth. The Economist. Disponível em: <http://www. economist.com/news/americas/21569706-more-inflation-less-growth-wrong-numbers >. Acesso em: 5 nov. 2016. 
da contabilidade criativa o seu habitat mais fértil. Apresentando indicadores cada vez mais fantasiosos, o governo tem uma forma de evitar o confronto com a realidade. Dentro desse contexto, torna-se cada vez mais comum o fenômeno das "despesas não orçamentais" (off budgets expenditures), ${ }^{24}$ referentes a operações que fogem à composição do orçamento e, portanto, da vista da sociedade e dos órgãos de controle, embaçando ainda mais a linha separatória entre o público e o privado.

O preço das políticas irresponsáveis que integram o extenso cardápio de inventividades contábeis sempre recai sobre o bolso do contribuinte. Permitam-me apresentar alguns itens deste mostruário.

Embora seja difícil esgotar o tema, em função de sua natural amplitude, sobretudo porque cada localidade, além do governo federal, desenvolveu formas próprias de burlar o orçamento e a LRF, é possível apresentar um quadro minimamente sistêmico de práticas que se enquadram no conceito de contabilidade criativa, destinadas a mascarar a realidade das contas públicas.

\section{Restos a pagar}

Sem dúvida, a medida mais recorrente é a postergação no pagamento de despesas correntes, acumulando quantias imensas em restos a pagar, os quais, a priori, não causam impacto no resultado primário das contas. Explico.

No âmbito das despesas, o estado brasileiro padece do velho hábito de deixar tudo para a última hora. $\mathrm{Na}$ esfera pessoal, é normal que cedamos à procrastinação e, assim, adiemos tarefas que deveríamos realizar imediatamente, mas que por preguiça, ou mero capricho, simplesmente deixamos de lado. Mas quando estamos falando de patrimônio público, a história não deveria ser assim. $\mathrm{Na}$ falta de verba, adiam-se pagamentos, e os dispêndios que deveriam ser feitos ao longo do exercício são deixados para o ano seguinte. ${ }^{25}$ Esses valores esquecidos no orçamento, correspondentes às despesas empenhadas (reservadas no orçamento) no exercício e não pagas até o seu encerramento, são transformados em restos a pagar, uma denominação técnica para compromissos assumidos e não pagos, que encontra disposição no art. 36, da Lei n. 4.320/64 e no art. 42, da LRF.

Ocorre que, ao registrar uma despesa em restos a pagar, o governo faz com esse valor escape à estatística fiscal oficial, uma vez que o resultado primário, equivalente à diferença entre a receita e a despesa primárias, é calculado com base no

24 SCHICK, Allen. Off-budget expenditure: an economic and political framework. OECD Journal on Budgeting, v. 7, n. 3, 2007, p. 2-3.

25 CONTI, José Maurício. Levando o direito financeiro a sério. São Paulo: Blucher, 2016, p. 141. 
chamado regime de caixa, que varia conforme a despesa é efetivamente paga, ou seja, no momento do desembolso financeiro, e não do empenho. Sempre que há um aumento do saldo de restos a pagar de um ano para o outro, isso significa que despesas estão sendo empurradas para o ano seguinte, a fim de promover um aumento contábil do superávit.

Sendo assim, a um só tempo, o governo altera artificialmente o cálculo final das contas, manipulando positivamente o resultado; compromete negativamente $\mathrm{o}$ orçamento do exercício seguinte, que terá de se preocupar com as despesas do orçamento anterior; como também consegue iniciar empreendimentos, embora não garanta a sua continuação, pois o impacto dar-se-á nas contas futuras.

Desta forma, um sem-número de obras são iniciadas, mas logo interrompidas e serviços que já foram prestados e liquidados (conferidos) ficam à espera de pagamento pelo governo. Em outras palavras, a verba está reservada no orçamento, o serviço foi efetivamente prestado, mas não é pago. Este possível calote do governo recorrentemente sustenta condutas imorais, como a exigência de propina para liberação dos pagamentos.

O uso do instrumento, por si só, não é reprovável. A imprevisibilidade natural da execução orçamentária ao longo de um exercício financeiro delimitado justifica que alguns gastos já empenhados sejam realizados em momento posterior, e isso tem previsão legal. Não se vê, contudo, na realidade, esse tipo de moderação. Ao invés disso, observa-se o uso e abuso deste recurso, criando uma espécie de orçamento paralelo. Uma realidade alterada que poderia ser chamada de orçamento-de-volta-para-o-futuro.

O Tribunal de Contas da União (TCU) manifestou preocupação neste sentido ao examinar o cenário das receitas e despesas primárias e o impacto na meta fiscal da União, referente ao $1^{\circ}$ quadrimestre de 2015 , entendendo que o uso desmesurado de inscrições e reinscrições de obrigações financeiras, principalmente relativas a despesas obrigatórias, na rubrica restos a pagar, afronta o princípio da anualidade orçamentária (art. 165, III, da Constituição Federal, c/c art. 2º da Lei n. 4.320/64) e o princípio da gestão fiscal responsável, previsto no art. $1^{\circ}, \$ 1^{\circ}$, da Lei de Responsabilidade Fiscal. ${ }^{26}$ Diante disso, através do Acórdão n. 2267/2016 - Plenário, determinou à

26 Art. $1^{\mathrm{o}}, \mathbb{S} 1^{\mathrm{o}}$ : A responsabilidade na gestão fiscal pressupõe a ação planejada e transparente, em que se previnem riscos e corrigem desvios capazes de afetar o equilíbrio das contas públicas, mediante o cumprimento de metas de resultados entre receitas e despesas e a obediência a limites e condiçôes no que tange a renúncia de receita, geração de despesas com pessoal, da seguridade social e outras, dívidas consolidada e mobiliária, operações de crédito, inclusive por antecipação de receita, concessão de garantia e inscrição em Restos a Pagar. 
Secretaria do Tesouro Nacional (STN) e à Secretaria do Orçamento Federal (SOF) que apresentassem plano de ação conjunto com medidas visando conter, nos próximos exercícios, o aumento do estoque de restos a pagar.

Não obstante isso, o tribunal apontou que tal desequilíbrio é crescente, além de ter demonstrado que a taxa de crescimento anual dos restos a pagar inscritos no período de 2001 a 2014, em especial nos últimos seis exercícios, foge a qualquer padrão aceitável. ${ }^{27}$

Ao valer-se dos restos a pagar para manipular o desempenho fiscal, os governantes fragilizam a transparência e, consequentemente, o controle dos gastos. É como se retornássemos às finanças da década de 1980, da conta de movimento e dos orçamentos paralelos. Parafraseando a poesia de Carlos Drummond de Andrade: Esse é tempo de partido, tempo de orçamentos partidos.

Potencializa-se, ainda, a briga dos credores pela liberação da verba atrasada no ano seguinte, cedendo espaço para negociações políticas maliciosas e pagamento de propinas, sem falar nos problemas de planejamento e gestão, que serão explorados mais à frente.

\section{Pedalada fiscal: operação de crédito?}

Outra artimanha contábil que tem se firmado nas finanças do setor público brasileiro e que retrata muito bem o problema do irrealismo orçamentário são as operações de crédito veladas.

Destaca-se, nessa categoria, pela grandeza e pelos desdobramentos que originou, as operações de créditos realizadas na gestão da Presidente Dilma Rousseff junto às instituições financeiras controladas pela União, por meio do atraso sistemático de repasse dos valores correspondentes ao financiamento de programas sociais do governo federal: as conhecidas pedaladas fiscais, tomaram conta dos noticiários e ocuparam o debate público ao longo de 2015-2016, tendo servido como fundamento central para eventos que marcaram a história recente do pais. Primeiro, a elaboração, pelo TCU, de parecer prévio pela rejeição das contas anuais de 2014 e 2015, o que não ocorria desde 1937. A rejeição de duas contas seguidamente, no entanto, é fato inédito. Segundo, o afastamento definitivo da Presidente da República, por intermédio do procedimento constitucional do impeachment, em agosto de 2016, por 61 votos no Senado Federal.

27 “(...) em termos nominais, o estoque de restos a pagar passou de $\mathrm{R} \$ 16$ bilhões em 2001, para R\$ 227 bilhōes em 2014, o que representa um aumento de mais de 1.300\%” (Acórdão n. 2823/2015 - Plenário, Rel. Min. José Múcio Monteiro, Ata n. 44/2015, Sessão de 04/11/2015). 
Pode-se afirmar que as pedaladas transformaram o cenário político e econômico do Brasil neste período e foram decisivas para o futuro da responsabilidade fiscal. Não é preciso ter um otimismo surrealista para encontrar lances positivos em meio à crise. Foi justamente em função dessa sucessão de acontecimentos históricos que a sociedade finalmente pôde abrir os seus olhos e ver mais claramente a nocividade da contabilidade criativa à saúde das finanças públicas. Desde então, é possível notar que a população tem dado mais atenção às questôes relativas ao Direito Financeiro, dando valor a matérias como a transparência orçamentária e a participação social no planejamento fiscal. E isso é bom, não só porque a lei orçamentária é, abaixo da Constituição, a norma mais importante no ordenamento jurídico, mas também porque as constantes arbitrariedades e atrocidades praticadas com dinheiro público mostraram como é perigoso deixar esquecidas essas reivindicações.

A pedalada fiscal é apenas uma dentre as inúmeras formas de criatividade ou destrutividade? - contábil. Desvendemo-la agora.

A forma como foi confeccionada a LRF revela que os legisladores já estavam cientes da vontade dos governantes em desviar das suas regras para obter recursos no presente, comprometendo a receita futura. Antecipando-se a este perigo, fizeram com que a lei abrigasse um conceito mais amplo de operação de crédito. A definição mais genérica, presente no art. 29, da LRF, portanto, não é algo aleatório.

Assim como as demais burlas que compõem o mostruário da contabilidade criativa, as pedaladas fiscais subsistiram pela soma de dois fatores: políticas imediatistas e a persistência em aumentar os gastos. O uso dessa artimanha foi, com efeito, o resultado de mais uma tentativa de simular uma situação positiva das contas, quando na verdade o cofre já estava devastado e a dívida insuperável.

Em suma, a fraude fiscal consistiu em atrasos no repasse, pelo Tesouro Nacional, de recursos públicos obrigatórios a instituiçôes financeiras controladas pela União para o pagamento de programas sociais, como o Bolsa Família, o Minha Casa Minha Vida, o Programa de Sustentação e Investimento (PSI) e o Plano Safra de financiamento agrícola, fazendo com que os bancos públicos (Caixa Econômica Federal, Banco do Brasil, Banco Nacional de Desenvolvimento Econômico e Social) arcassem, com patrimônio próprio, a continuidade desses programas, em nome do governo federal. Com os bancos sendo obrigados a financiar essas despesas, instituiu-se uma operação de crédito, sob a forma de empréstimo.

Diferentemente do chefe de família, que, em período de vacas magras, pode recorrer aos bancos para contrair empréstimos ou usar o cheque especial, o poder 
-• Finanças públicas: travessia entre o passado e o futuro

público não dispõe dessa alternativa com relação aos bancos públicos, pois a lei veda que os entes políticos realizem operações de crédito com instituições financeiras controladas por eles mesmos. É o que prevê o art. 36 da Lei de Responsabilidade Fiscal, e foi isso o que aconteceu.

Ao não repassar esse montante, o governo conseguiu "maquiar" as contas, apresentando despesas menores do que aquelas que realmente haviam efetuado, pois embora os benefícios estivessem sendo pagos, por intermédio da Caixa, por exemplo, não eram contabilizados como despesas no resultado primário da União, através do aumento da dívida do Tesouro junto à instituição financeira. Os déficits orçamentários que vinham ocorrendo desde 2014, portanto, seriam bem piores se fosse considerado o valor das pedaladas, que chegou ao total de $\mathrm{R} \$ 72$ bilhões. ${ }^{28} \mathrm{Os}$ bancos públicos converteram-se no próprio cheque especial.

Essa camuflagem fiscal só foi possível, contudo, porque o Banco Central, responsável pela elaboração do indicador oficial de endividamento do setor público brasileiro, isto é, da divulgação dos saldos das dívidas públicas, deixou de registrar no passivo as dívidas que as pedaladas geravam com os bancos públicos. ${ }^{29}$ Essa omissão permitiu que despesas que deveriam ser cortadas, não o fossem, e assim o orçamento ficasse mais livre para o descontrole. Destarte, esses recursos foram desviados para o pagamento de outras obrigaçóes menos importantes para a sociedade, mas prioritárias para um ano de eleições.

Vê-se, portanto, que o termo, pedaladas fiscais não é apenas uma figura de linguagem, mas uma fraude contábil gravíssima, antitética à ideia de responsabilidade fiscal. Não é à toa que essa operação encontra previsão como crime na Lei n. 7.482/86 (Lei do Colarinho Branco), em seu art. 17 e que tenha sido incorporada à Lei do Impeachment (Lei n. 1.079/50), como crime de responsabilidade, no art. 10, item 9, pela Lei n. 10.028/2000. O impeachment em nome da responsabilidade fiscal é o retrato da gravidade dessa conduta.

Assim entendeu o Tribunal de Contas da União, ao julgar o processo de representação específico sobre esses atrasos e condenar os responsáveis à multa e inabilitação para ocupar cargo ou função na Administração Pública. (Acórdão n. 2.575/2016 - Plenário, Rel. Min. José Múcio Monteiro, Ata n. 39/2016).

28 Total pago de 'pedaladas' este ano soma R \$ 72,4 bilhões. Valor Econômico. Disponível em: $<$ http://www.valor.com.br/brasil/4374582/total-pago-de-pedaladas-este-ano-soma-r-724-bilhoes >. Acesso em: 25 out. 2016.

29 TCU, Acórdão n. 825/2015, Rel. Min. José Múcio Monteiro, Ata n. 13/2015, Sessão de $15 / 04 / 2015$. 


\section{Crise fiscal e contabilidade criativa nos Estados e Municípios}

Quem pensa, entretanto, que esse desastre financeiro e a forma maliciosa de lidar com ele se restringe ao governo federal e, por isso, é um problema exclusivo do Presidente da República, engana-se. A crise fiscal atingiu em cheio os estados e municípios brasileiros, de maneira que estes estão em situação tão dramática quanto a União, e se valem de formas semelhantes de criatividade contábil, além de outras tantas ainda mais criativas para escapar das normas legais.

O que vemos, hoje, em âmbito estadual principalmente, é uma situação geral de insolvência, na qual os entes se veem encurralados por dívidas bilionárias e dificuldades financeiras para continuar prestando os serviços públicos mais básicos ou para pagar o salário dos funcionários públicos. Assim, tornou-se comum a publicação de notícias de que a inadimplência de determinados estados perante fornecedores tem prejudicado serviços importantes como o atendimento em hospitais e o funcionamento de escolas, ${ }^{30}$ ou, ainda, informações de entes que parcelaram ou simplesmente não conseguem pagar o décimo terceiro salário dos servidores públicos, lavando as mãos e pondo-se à espera de algum milagre.

Neste contexto, algumas entidades chegaram a declarar o que autodenominaram de calamidade financeira, ${ }^{31}$ o equivalente, em termos mais realísticos, à falência múltipla dos órgãos ou, ainda, quando a vaca encontra o brejo.

Acredite ou não, o quadro é pior do que aparenta ser, na medida em que vários estados fecharam o ano de 2017 com rombo nas contas públicas, ou seja, com as despesas primárias superiores às receitas.

No caso dos municípios brasileiros, a situação é igualmente preocupante: os novos prefeitos de quase a metade das capitais brasileiras assumiram o seu mandato em janeiro/2017 com uma série de dificuldades para pagar servidores e fornecedores, tendo inclusive de encurtar o horário de aula nas escolas em função da paralisação no fornecimento de merendas. Uma análise mais geral da Confederação Nacional dos Municípios (CNM), com base em dados providos por

30 Crise nos Estados afeta serviços essenciais. O Globo. Disponível em: <http://oglobo.globo. com/brasil/crise-nos-estados-afeta-servicos-essenciais-20451167>. Acesso em: 11 nov. 2016.

31 O "Estado de calamidade pública" é previsto de forma expressa na Lei Complementar n. 101/2000. Não obstante isso, é bastante controverso o enquadramento da crise financeira à hipótese de calamidade pública. O Rio de Janeiro, em 17 de junho de 2016, por meio Decreto n. 45.692/16, estrategicamente pouco antes da realização dos Jogos Olímpicos; Rio Grande do Sul, em 22 de novembro, através do Decreto n. 53.303/2016; e Minas Gerais, por último, em 5 de dezembro, por intermédio do Decreto n. 47.101/2016. 
-• Finanças públicas: travessia entre o passado e o futuro

3.155 municípios, mostra que $75 \%$ começaram a nova gestão (2017/2020) com as contas no vermelho (2.443 municípios com déficit fiscal). No total, calcula-se um buraco de $\mathrm{R} \$ 69$ bilhões nos cofres municipais. ${ }^{32}$

$\mathrm{Na}$ maioria das cidades, houve uma piora significativa na relação dívida/receita. Os gastos, especialmente os obrigatórios (previdência, pessoal) cresceram além da conta. No caso das despesas com pessoal, o caos é semelhante àquele verificado nos estados: entre 2014 e 2016, mais que dobrou o percentual de municípios com mais de 200 mil habitantes que, nesse quesito, ultrapassaram os limites da LRF, comprometendo mais do que $60 \%$ da receita com o pagamento de salários e inativos. De nove municípios, em 2014, para vinte e quatro, em 2016. ${ }^{33}$ Muitos prefeitos já iniciaram o ano também decretando o estado de calamidade financeira. ${ }^{34}$

A culpa dessa crise subnacional é geralmente atribuída a fatores externos e à queda de arrecadação da União, o que teria afetado drasticamente o repasse de recursos federais aos estados e municípios, por meio dos Fundos de Participação, principal fonte de receita desses entes. Embora o problema de arrecadação-repasse exista, somado ainda às várias desoneraçôes fiscais concedidas pela União, é certo que a razão decisiva reside em outro fator: na irresponsabilidade fiscal levada anos a fio pelos governadores e prefeitos, especialmente em relação aos gastos, expandidos além da capacidade financeira. ${ }^{35}$

O que permitiu que a situação chegasse a tal ponto, entretanto, não foi o gasto descontrolado por si só, mas o contínuo uso de burlas fiscais, por intermédio da contabilidade criativa, para escondê-lo da população e fazer parecer que havia certo equilíbrio no orçamento, quando na realidade a equação receita/despesa já há muito se encontrava insustentável.

Aqui, o cardápio é extenso.

32 AMORIM, Silvia. Rombo no cofre de municípios chega a R \$ 69 bilhōes, aponta levantamento". O Globo. Disponível em: <http://oglobo.globo.com/brasil/rombo-no-cofre-de-municipios-chega-r-69-bilhoes-aponta-levantamento-20422628>. Acesso em: 30 nov. 2016.

33 "Municípios começam ano com mais dívidas, peso da folha e menor previsão de receitas, $O$ Globo. Disponível em: <http://oglobo.globo.com/brasil/municipios-comecam-ano-com-mais-dividas-peso-da-folha-menor-previsao-de-receita-20716005 >. Acesso em: 1 jan. 2017.

34 TOMAZELLI, Idiana. Desde o ano passado, 62 municípios decretaram calamidade financeira. O Estado de S.Paulo. Disponível em: <http://economia.estadao.com.br/noticias/geral, desde-o-ano-passado-62-municipios-decretaram-calamidade-financeira,10000100510>. Acesso em: 16 jan. 2017.

35 ABRAHAM, Marcus. Estado de calamidade financeira e lei de responsabilidade fiscal. Coluna Fiscal de 07 de julho de 2016, Jota. Disponível em: <http://jota.info/colunas/coluna-fiscal/ coluna-fiscal-estado-de-calamidade-financeira-e-lrf-07072016>. Acesso em: 12 out. 2016. 
Pode-se apontar como modalidades mais recorrentes no âmbito estadual: a) a abertura de créditos adicionais de forma irregular, isto é, sem a devida autorização legislativa ou fora dos limites impostos em lei; b) o cancelamento excessivo de empenhos, aumentando a conta de restos a pagar e; c) atos que alteram a equação das despesas com pessoal, a fim de adequar-se aos limites da LRF. Essa última modalidade, pela sua variedade, deve ser olhada mais de perto.

Antes, porém, é preciso fazer aqui uma crítica - ou autocrítica, se assim preferirem. Esse rol de práticas lesivas às finanças públicas tivera nos órgãos de fiscalização um grande incentivador, na medida em que a assimetria de entendimentos nos tribunais de contas estaduais possibilitou que passassem ilesas as ações de contabilidade criativa. Ao não se opor prontamente a tais formas de esconder os números, as cortes acabaram avalizando uma gestão financeira temerosa, que agora dá os seus frutos. Podres.

Em Minas Gerais e Rio Grande do Sul, o Ministério Público que atua junto ao Tribunal de Contas opinou pela rejeição das contas anuais prestadas pelo governador, por terem verificado irregularidades graves que serviram para maquiar as finanças estaduais. O MPC/MG apontou exagero no cancelamento de empenhos e inscrição em restos a pagar ( $\mathrm{R}$ \$ 1,13 bilhão), em 2014, ${ }^{36}$ e o uso indevido de depósitos judicias como receita corrente líquida, com vistas a aumentar artificialmente o caixa do estado e melhorar o resultado das contas, em 2015. ${ }^{37}$ No Rio Grande do Sul, o MPC/RS ${ }^{38}$ verificou a abertura indiscriminada e fundamentada em um "excesso de arrecadação" que não existia na realidade, de créditos suplementares ( $\mathrm{R}$ 1,9 bilhão), além do pagamento do décimo terceiro salário de servidores públicos mediante empréstimo (operação de crédito) realizado junto ao Banrisul (Banco do Estado do Rio Grande do Sul S/A), em caso muito semelhante às pedaladas fiscais do governo federal em 2014-2015. Ocorre que, a despeito dessas ilegalidades, em todos os casos, os tribunais de contas decidiram aprovar as respectivas prestaçóes de contas. O TCE-MG, em 21 de novembro de 2016, aprovou por maioria o Balanço Geral do Estado de 2015.

36 Relatório do Balanço Geral do Estado n. 951.454, Rel. Cons. Gilberto Diniz, sessão plenária de 9 de julho de 2015, p. 100.

37 Ministério Público de Contas do Estado de Minas Gerais, parecer processo n. 977590/2015. Balanço Geral do Estado de Minas Gerais, de 2015. Disponível em: <http://minasdeverdade.com.br/wp-content/uploads/2016/07/Parecer-Processo-977590.pdf>. Acesso em: 22 out. 2016.

38 Ministério Público de Contas do Estado do Rio Grande do Sul, Parecer n. 10143/2016, Processo n. 4152-02.00/15-0. 
-• Finanças públicas: travessia entre o passado e o futuro

Isso é mais do que suficiente para estabelecer a sintonia fina existente entre a contabilidade criativa e a destruição fiscal. No caminho entre uma e outra, situa-se a opacidade e a corrupção.

Como foi adiantado acima, há um ponto específico que causa perturbação àqueles que acompanham as finanças do estado e merece atenção especial, precisamente por ser aonde é maior o nível de gasto e, por consequência, onde mais se busca esconder as despesas através da contabilidade criativa: nas despesas com pessoal. No cenário de dribles à LRF, poderíamos dizer que a despesa com pessoal desperta nos gestores a mesma habilidade de um Neymar Júnior em um dia muitíssimo inspirado.

A Constituição Federal de 1988, pretendendo de antemão impedir o crescimento exagerado dos gastos com o funcionalismo público, estabeleceu no art. 169 que uma lei complementar fixasse limites específicos que cada ente deveria respeitar. A lei complementar n. 101/2000 (LRF) ocupou-se desse papel e estipulou que a União não poderia comprometer mais do que $50 \%$ de sua receita corrente líquida; e os estados e municípios, $60 \%$, com pagamento de servidores públicos ativos e inativos e pensóes.

A mesma Lei de Responsabilidade Fiscal previu, ainda, mecanismos automáticos para quando este limite estiver próximo de ser atingido, como os alertas emitidos pelos Tribunais de Contas ${ }^{39}$ e sanções rigorosas nos casos em que houver descumprimento.

Justamente para evitar a imposição dessas duras penalidades, sem que tivessem de reduzir o ritmo de nomeações políticas e concessões de benefícios aos setores de pressão, os governantes fizeram com que estes números não fossem revelados com grande transparência. Assim, o gasto poderia crescer, atendendo aos reclames do corporativismo, sem aparecer, mantendo uma aparência dissimulada de responsabilidade fiscal junto à população. $\mathrm{O}$ melhor dos dois mundos. Simulação e dissimulação, de uma só vez.

E como cresceu: segundo o Tesouro Nacional, somente entre 2014 e 2015, o crescimento médio de despesas com pessoal foi de 13,06\% nos Estados e 8,29\% nos municípios com mais de 200 mil habitantes. ${ }^{40}$

39 No art. 59, 10, II, da LRF, consta que as Cortes de Contas irão emitir alerta aos Poderes e órgãos quando constatarem que o montante da despesa total com pessoal ultrapassou $90 \%$ do limite. Atualmente, tem sido intensificado o seu uso.

40 STN divulga novo boletim de finanças de estados e municípios. Secretaria do Tesouro Nacional. Disponível em: <https:/www.tesouro.fazenda.gov.br/-/stn-divulga-novo-boletim-de-financas-de-estados-e-municipios>. Acesso em: 29 nov. 2016. 
E como não apareceu: segundo dados também do Tesouro Nacional, ${ }^{41}$ a dívida com pessoal informada pelos governos locais era muito inferior àquela que realmente existia. Essa diferença foi verificada pelo Tesouro ao comparar os gastos com pessoal autodeclarados pelos estados no Demonstrativo das Despesas com Pessoal, divulgado no Sistema de Informações Contábeis e Fiscais do Setor Público Brasileiro - SICONFI, com os dados do Programa de Reestruturação e de Ajuste Fiscal, formulado pela Secretaria do Tesouro Nacional para monitorar as contas estaduais e autorizar operações de crédito, e que não levam em conta as manobras utilizadas pelos governadores para diminuírem a despesa com pessoal a fim de se enquadrarem nos limites da LRF.

De acordo com os dados informados pelos próprios estados, somente duas unidades da federação estavam ultrapassando o limite no fim de 2015. No entanto, ao utilizar os critérios do Tesouro Nacional e extrair a criatividade contábil, nove estados passaram a estourar o teto: Distrito Federal (64,74\%), Goiás (63,84\%), Minas Gerais (78\%), Mato Grosso do Sul (73,49\%), Paraná (61,83\%), Rio de Janeiro (62,84\%), Rio Grande do Sul (70,62\%), Paraíba (61,86\%) e Tocantins (63,04\%).

Como essas discrepâncias foram possíveis e por tanto tempo? Como a criatividade contábil acontece e, assim, afeta os gastos com pessoal?

A divergência é produto de artifícios que os governadores utilizam para alterar o cálculo final e adequar-se ao art.19, II, da LRF. Tais burlas acontecem de duas formas: primeiro, deduz-se algumas despesas que passam a não serem declaradas como "gastos com pessoal" e, portanto, não integram o cálculo final, escapando ao limite de 60\%, mas que deveriam ser emolduradas nesse elemento de despesa, uma vez que a Lei de Responsabilidade Fiscal estabelece taxativamente todas as hipóteses em que a dedução é permitida. Assim acontece nos casos de exclusão do Imposto de Renda Retido na Fonte (IRRF) dos servidores; exclusão dos valores relativos ao Programa de Saúde na Família do limite; aumento excessivo de despesas indenizatórias, que passam a ser concedidas de forma não eventual, pois não são contabilizadas como remuneração do servidor, e tantas outras hipóteses. Segundo, criando subterfúgios para gerar caixa temporariamente, aumentando a receita por tempo limitado. Nesse caso, o cardápio oferece medidas que vão desde operações de crédito com bancos públicos para viabilizar o pagamento de salários e décimo terceiro, à utilização de depósitos judiciais como fonte de receita.

$411^{\text {a }}$ edição do Boletim de Finanças Públicas dos Entes Subnacionais de 2016. Disponível em: <https://www.tesouro.fazenda.gov.br/documents/10180/337275/Boletim+entes+2016/ e4428e40-5256-40f9-91f6-ee8dcb377a25>. Acesso em: 29 dez. 2016. 
-• Finanças públicas: travessia entre o passado e o futuro

Esse último método, por ser mais recente e ter gerado grande controvérsia a respeito da sua legalidade, que ainda aguarda resolução definitiva do Supremo Tribunal Federal ${ }^{42}$, reclama uma breve análise em separado.

O problema desse método, autorizado pela Lei Complementar n. 151/2015 e replicado em diversos estados da federação, encontra-se no fato de que os recursos oriundos dos depósitos judiciais são transitórios e atípicos, ou seja, não integram os cofres do Estado de forma permanente, como acontece, por exemplo, com as receitas provenientes do pagamento de impostos, que sai do bolso do contribuinte e passa a pertencer definitivamente ao Estado. Além disso, essa receita de depósitos provém de terceiros que, ao final do processo judicial, terão de receber o dinheiro depositado, ou seja, são valores extraordinários, que terão de ser devolvidos futuramente. Os leitores mais atentos já devem ter notado que há uma denominação apropriada para isso e que não por acaso já apareceu diversas vezes neste livro: operação de crédito. Isso porque o poder público assume uma obrigação futura, visto que esse dinheiro já ingressa no cofre com data marcada para sair. Seria o equivalente a um empréstimo entre o Tesouro Público dos entes federativos e os depositantes.

O fôlego que essa prática parece dar às contas assemelha-se mais a um placebo orçamentário, pois pelo aumento da dívida, busca-se uma receita incerta, quase imaginária, para custear gastos que não param. Como já sabemos, adiar a resolução dos problemas de fundo, gerando outros mais graves ainda no futuro, constitui a ideia central da contabilidade criativa e é justamente o que mais desequilibra o orçamento.

Para finalizar a (necessariamente) longa parte desse livro, pretendo ainda dar ênfase a uma modalidade incipiente de maquiagem contábil. Uma preocupação que desejo compartilhar aqui para que os leitores fiquem atentos a essa prática que tem se tornado recorrente na administração das finanças públicas. Trata-se do inchaço das "Despesas de Exercícios Anteriores", mais conhecidas como DEA.

Essa rubrica chamada "Despesas de Exercícios Anteriores" congrega os gastos que ocorreram, mas para os quais não houve registro e nem foi utilizado o orçamento da época, ou seja, são despesas que se dão à margem do orçamento, a exemplo

42 ADI's n. 5353/MG, 5072/RJ, 5351/DF, 5409/BA. O STF tem entendido ainda em juízo sumário e provisório, que tais leis estaduais são inconstitucionais por violarem: Princípio da separação de poderes; iniciativa privativa legislativa da União (art. 22, I - matéria processual); A Lei Complementar n. 151/2015 apenas autoriza o levantamento de 70\% dos valores que sejam objeto de depósitos vinculados a processos em que os entes federados sejam parte (art. 20) (STF, Plenário, ADI 5353 MC-Ref/MG, Rel. Min. Teori Zavascki, julgado em 28.09.2016). 
daquelas que não foram processadas a tempo, ou referente a compromissos reconhecidos após o encerramento do exercício. Exatamente por não constar na peça de planejamento, uma vez que a regra mais básica e elementar do gasto público é que ele seja autorizado por lei (orçamento), é que a DEA deveria incluir somente despesas excepcionalíssimas. Porém, como todo bom jeitinho brasileiro, esse caráter de exceção tem sido distorcido, havendo um evidente exagero de valores dispendidos dessa forma, o que vai de encontro a qualquer exigência de planejamento. Em 2015, foram R \$ 16,5 bilhôes, num conjunto de 24 estados. Um aumento de 44\% em relação a 2014 ( $\mathrm{R} \$ 11,4$ bilhões $){ }^{43}$

Apesar de parecidos na forma e utilizados para o mesmo fim espúrio de maquiar as contas, as DEA não se confundem com os restos a pagar, que ao menos passam pelo orçamento do ano como despesas que foram empenhadas, mas que por deficiência no planejamento deixaram de ser pagas. As DEA, por sua vez, formam um esqueleto orçamentário que possibilita aos estados esconder os gastos debaixo do pano grosso da desfaçatez, a fim de melhorar os indicadores da meta primária ao final do ano. Não é por acaso que, nos últimos anos, estas (RP e DEA) tenham sido as duas rubricas cujos valores mais aumentaram.

Em que pese esse cenário fiscal desanimador, não há fortes motivos para crer que a contabilidade criativa deixará de prevalecer nas contas brasileiras. Geralmente, imputa-se a culpa à LRF, sobretudo ao rigor e inflexibilidade de seus dispositivos. $\mathrm{O}$ problema não está na lei, mas na sua aplicação, ou má-aplicação. Em 18 anos de vigência, poucos de seus dispositivos foram realmente aplicados como deveriam.

O problema, portanto, é exógeno à lei. Não há incentivos concretos à implementação da transparência na execução orçamentário-financeira, o que resulta em indicadores maleáveis, que podem ser facilmente simulados e dissimulados ao gosto de interesses políticos. Além disso, observa-se ainda grande leniência dos órgãos de controle, tanto dos Tribunais de Contas, que vêm falhando principalmente no controle preventivo, como da própria Secretaria do Tesouro Nacional, em relação aos entes subnacionais, pois funciona - ou deveria funcionar - como fiscalizador das finanças dos Estados, com poder de aplicação de medidas administrativas e edição de regras de consolidação das contas.

Assim, vão se proliferando os ajustes artificiais, que embora cômodos do ponto de vista político, apenas posterga a solução para os problemas que mais inquietam

43 Estados tem esqueletos de despesas de R\$ 15 bilhões. Valor Econômico. Disponível em: <http://www.valor.com.br/brasil/4606193/estados-tem-esqueletos-de-despesas-de-r-15-bi>. Acesso em: 29 nov. 2017. 
a sociedade. Todos sabemos, afinal, quem tem de arcar com os custos das escolhas fáceis, porém incompetentes, uma vez que a verdade sai do poço sem indagar quem se acha à borda, como alertou Machado de Assis. A lição é antiga e até as crianças já sabem que quanto mais se esconde uma mentira, mais difícil vai se tornando contá-la.

Justamente porque encurta as pernas dessa mentira é que o controle não pode falhar. Deve ser eficiente e preciso para exigir que as normas sejam cumpridas. As possíveis soluções serão apresentadas nos próximos capítulos, mas uma lição já se espera ter-se absorvido: a contabilidade criativa cria menos dinheiro do que oportunidades para má-gestão.

\section{No curso das ações políticas: ausência de planejamento}

É impossível dissociar a escassez de transparência da questão do planejamento. No fim das contas, o irrealismo orçamentário é também um problema de falta de planejamento orçamentário eficiente e, portanto, de gestão racional do dinheiro público. Por isso a necessidade de colocá-los em um mesmo tópico. Quando a contabilidade criativa, as pedaladas e as maquiagens contábeis em geral combinam-se com a má-gestão do patrimônio estatal, a responsabilidade fiscal corre sérios riscos, e a corrupção é um efeito quase que natural.

Planejar as finanças governamentais é tão essencial quanto à própria prestação dos serviços públicos. Já se foi o tempo em que o orçamento refletia um quadro frio das receitas e despesas públicas. Deixou de ser um mero documento contábil, para espelhar a vida econômica do país, e, portanto, a vida dos seus cidadãos. ${ }^{44}$ Não é exagerado dizer que o orçamento é o espelho do futuro do país, dos estados e de seus municípios. Materializará os direitos do presente e o legado que vai deixar às próximas geraçóes, se de prosperidade ou endividamento pelos gastos de agora. E, como disse certa feita o cineasta Woody Allen, é lógico que o futuro nos importa, pois é nele que passaremos o resto de nossas vidas.

Seja na fonia, como no conteúdo, orçamento rima com planejamento. ${ }^{45}$ São inseparáveis, de modo que, se um realizar-se sem o outro, nenhum funcionará

44 HARADA, Kiyoshi. Direito financeiro e tributário. 25. ed. rev. atual. São Paulo: Atlas, 2016, p. 67.

45 Com a Constituição de 1988, o planejamento ganhou status constitucional, eis que, no art. 174, foi transferido de mero ordenador da atividade administrativa em principal instrumento na atividade econômica. (BOGOSSIAN, Andre. Levando o orçamento a sério como instrumento de controle das políticas públicas. Revista Brasileira de Políticas Públicas, Brasília, v. 5 , n. 2, p. 178-198, 2015). 
adequadamente. Isso se aplica perfeitamente às finanças domésticas e empresariais. No caso da Administração Pública, porém, a importância é sobrelevada, pois estamos falando do dinheiro da coletividade. Nesse meio, a falta de planejamento não resulta somente em frustrações, mas em enormes desperdícios e corrupção.

Portanto, é com segurança que se pode afirmar: sem um planejamento claro, detalhado e bem elaborado, a lei orçamentária ganha, então, contornos de faz de conta. Afinal, uma sociedade que não leva a sério o seu planejamento aceita qualquer resultado no final das contas. ${ }^{46}$

O planejamento orçamentário brasileiro é definido na Constituição Federal como elemento essencial da atividade econômica e se materializa pelos instrumentos de previsão de metas, programas e diretrizes da administração pública. São eles: o Plano Plurianual (PPA), válido por quatro anos, que prevê diretrizes e metas a médio e longo prazo, iniciando-se no segundo ano do mandato do chefe do Poder Executivo até o final do primeiro ano de exercício; a Lei de Diretrizes Orçamentárias (LDO), com duração de um ano, que estipula metas e prioridades para o governo no exercício, funcionando como elo de conexão entre o PPA e a Lei Orçamentária Anual (LOA), que estabelece com maior nível de detalhamento de onde retirar e aonde gastar os recursos públicos naquele exercício. Em todos os casos, a iniciativa é do Poder Executivo, devendo os respectivos projetos e as propostas serem remetidos ao Poder Legislativo para aprovação.

Em 2000, a LRF nasceu e buscou aperfeiçoar o sistema de planejamento governamental já estabelecido na Constituição e na Lei n. 4.320/64, conferindo mais ênfase às ferramentas de médio e longo prazo, como o Anexo de Metas Fiscais, na LDO. A intenção era privilegiar um equilíbrio fiscal que fosse durável e não precário.

O menosprezo que esses instrumentos de planejamento recebem dos políticos, no entanto, é uma triste constatação que a cada dia se torna mais evidente. Defeito que certamente é um dos principais responsáveis pelo desmantelo fiscal do presente. ${ }^{47}$ Vários atos e omissões se somam de modo a deixar claro que o planejamento no Brasil é a crônica de uma morte (fiscal) anunciada, como na obra de Gabriel García Márquez.

O governo funciona, basicamente, como o arquiteto que discute as condiçōes dos cômodos numa casa em ruínas, consertando uma porta aqui ou remendando uma infiltração acolá, sem considerar as condições gerais da edificação.

46 CONTI, José Maurício. Levando o direito financeiro a sério. São Paulo: Blucher, 2016.

47 CONTI, José Maurício. Levando o direito financeiro a sério. São Paulo: Blucher, 2016, p. 78. 
- Finanças públicas: travessia entre o passado e o futuro

A começar pelo recorrente atraso com que são aprovadas as leis orçamentárias. A própria União já ficou, em duas oportunidades e por um prazo razoável, sem orçamento aprovado, sem que isso afetasse a rotina do governo. Em 2015, chegamos ao ponto de iniciar o ano, vejam, sem um orçamento para a União. Em outros países, o mesmo atraso resulta em paralisações caóticas do governo, como ocorreu nos Estados Unidos, no shutdown (paralisação do governo), em 2013.

Principalmente a LDO e a LOA, por serem leis de vigência anual, devem ser renovadas dentro do prazo estabelecido no Ato das Disposições Constitucionais Transitórias. ${ }^{48}$ Ocorre que constantemente essas leis não são aprovadas até o final do ano, iniciando-se o exercício financeiro com uma lacuna de autorização orçamentária, na qual os gastos são efetuados sem autorização de lei alguma, ou seja, sem aval formal do povo. Gasta-se sem lastro e, portanto, sem possibilidade de controle. A existência da norma orçamentária não constitui formalidade e, portanto, a sua ausência é gravíssima e afeta drasticamente o planejamento. Não foi por acaso que a Constituição Federal (art. 57, $\$ 2^{\circ}$ ) determinou que a sessão legislativa não seja interrompida enquanto não for aprovada a Lei de Diretrizes Orçamentárias.

Outro problema crônico é a completa ausência de reflexão e discussão sobre as prioridades da sociedade e a alocação dos recursos (limitados) do Estado, quando da elaboração dos planos e leis orçamentárias. As técnicas de planejamento orçamentário, criadas há mais de século para conferir eficiência às alocações, foram progressivamente substituídas pela vontade de atender bases eleitorais e formar coalizões.

Até hoje, as prioridades não são definidas com clareza, pois isso implicaria reconhecer que algumas demandas serão atendidas e outras não, o que os governantes se recusam a fazer, pois preferem esconder-se em um mundo de aparências onde todas as necessidades poderão ser atendidas e os recursos são ilimitados. Assim, a elaboração das leis de orçamento passa a ser um jogo de improvisação, de imagem sem ação.

Os avanços em áreas cruciais e muito sentidas atualmente, como educação, saúde, saneamento e segurança pública, reclama planejamento a longo prazo, porém os incentivos estabelecidos levam as autoridades a fazer escolhas visando resultados num horizonte muito mais curto. O PPA, que representa essa programação sustentável de longo prazo, é encarado como uma formalidade. Em todos os entes, mas especialmente nos municípios menores, o PPA é um documento extremamente

48 Art. 35, $₫ 2^{\circ}$, I, do ADCT/88. São prazos de natureza federal, aplicáveis, portanto, à União somente. Os demais entes da federação fixam datas próprias para a aprovação e discussão das normas orçamentárias estaduais e municipais. 
genérico, elaborado com base em modelos pré-elaborados que se repetem anualmente. Um único modelo serve a diversas municipalidades, como se as necessidades fossem idênticas em todas as regiōes. Vaga assim, a norma orçamentária abraça a tudo e a todos, mas acaba não servindo para quase nada. ${ }^{49}$

O Poder Legislativo, a quem caberia questionar e discutir a proposta orçamentária proveniente do Poder Executivo, adequando-a aos anseios da população que representa, volta a sua atenção exclusivamente à destinação das emendas parlamentares, que irão compor a sua base eleitoral e, não raras vezes, servir como pretexto para práticas corruptas, dando um passe quase-livre aos gestores para o gerenciamento dos cofres públicos. Dessa forma, no modelo orçamentário brasileiro, com maior intensidade nos municípios, a escolha de como e quando; fazer ou não fazer; gastar ou não gastar, fica nas mãos dos burocratas e para a fase de execução. Literalmente na última hora.

Assim, a Lei Orçamentária Anual, que deveria corresponder tão somente à parte final de um longo processo de planejamento da ação governamental, transforma-se em uma lei distante das demais (LDO e PPA), sem indicadores claros para seguir e sem objetivos críveis para alcançar, seguindo um programa de liberação definido arbitrariamente pelo gestor. O que teria ocorrido com o art. $165, \$ 4^{\circ}$, da Constituição de 1988, que determina a consonância obrigatória com o PPA? Ou com o art. $1^{\circ}$, da LRF, que requer uma gestão fiscal responsável por meio da ação planejada e transparente do governo? E o Anexo de Riscos Fiscais da LRF, que deveria prever medidas preventivas e, assim, impedir ações improvisadas, mas que dificilmente aparece na LDO $?^{50}$ São perguntas cuja resposta se perdeu nesse caminho obscuro que estamos traçando.

Este orçamento-improviso, de véspera, acaba permitindo graves desvios na realização dos gastos públicos, que passam ao largo do conhecimento dos cidadãos. São várias as distorçôes que aumentam a distância do que está no papel e foi aprovado pelo parlamento, da realidade. Um conjunto de práticas que esvaziam a peça orçamentária e levam muito dinheiro público para o ralo. E, em resumo, as principais são: a superestimação de receitas; o contingenciamento de despesas; a anulação de valores empenhados; e a realocação de verbas por meio de remanejamento.

49 CONTI, José Maurício. Levando o direito financeiro a sério. São Paulo: Blucher, 2016, p. 55.

50 Por exemplo, o Acórdão n. 255/2015 - Pleno - TCE/PR, referente ao Parecer Prévio das Contas de Governo do Paraná, apontou como irregularidade a ausência do Anexo de Riscos Fiscais, o que a acabou sendo ressalvado na apreciação final do plenário. Em 2016, pelo Acórdão n. 223/20016 - Plenário, o tribunal reiterou essa deficiência ao verificar que a ressalva não foi atendida no exercício seguinte. 
-• Finanças públicas: travessia entre o passado e o futuro

Se no passado a inflação galopante impedia que a fixação das despesas fosse real, uma vez que os valores mudavam diariamente, hoje, criou-se o hábito de superestimar as receitas, de modo a ensejar gastos bem maiores do que os cofres comportam. Nesse sentido, aumenta-se as estimativas de receita, com vistas a acomodar inúmeras despesas, atendendo à pressão de grupos de interesse para manter certos privilégios (de reajustes até desonerações tributárias). Assim, o orçamento torna-se um repositório de quantas promessas políticas consiga-se formular, já que quanto maior for o bolo, mais fatias poderão ser distribuídas para grupos específicos.

Com isso, transfere-se para o Poder Executivo a liberdade de decidir, na boca do caixa, o quanto será destinado e para quem. O que não significa boa prática, pois a discricionariedade é inegavelmente um fator que impulsiona a corrupção, sobretudo quando associada à falta de fiscalização. ${ }^{51}$

Nesse particular, há uma clara negligência do Poder Legislativo ao aprovar orçamentos superestimados. Isso acontece porque, no Brasil, prevalece a ideia de que o orçamento é autorizativo e não impositivo, ou seja, que a sua execução não deve ser obrigatoriamente igual àquilo que foi aprovado no parlamento, tendo em vista a necessidade de manter certa flexibilidade para se adequar às imprevisões da economia. Em suma, representa o poder de não gastar naquilo que fora planejado. Porém, orçamento autorizativo nunca significou dinheiro ilimitado. Isso quem afirma é a própria LRF, ao exigir que as previsōes de receita observem normas técnicas e legais, para que sejam confiáveis; e não previsões inadequadas, que deixem para a fase de execução os ajustes discricionários.

Quando esse orçamento inchado ingressa na realidade, caindo a ficha de que aquela receita era intangível e que agora faltam recursos para tantas despesas, as autoridades passam a realizar cortes aonde melhor lhes aprouver, sem o mínimo de transparência, por intermédio das limitações de empenho e movimentação financeira, tecnicamente conhecidas como contingenciamentos.

Obviamente, como a lei orçamentária é uma previsão que não mostra exatamente tudo o que entrará e sairá dos cofres e que depende, em certa medida, de uma série de condiçỗes futuras, sobretudo da atividade econômica, alguns cortes podem mostrar-se necessários no decorrer do exercício financeiro. Mas também é óbvio que o abuso desse instrumento, deformando o processo orçamentário, é totalmente inverso à ideia de planejamento e transparência das ações de governo, pois distancia ainda mais o orçamento da realidade.

51 JAIN, Arvind K. Corruption: a review. Journal of Economics Surveys, v. 15, n. 1, p. 16-19. 
Além disso, o seu uso indiscriminado tem vínculo estreito com a corrupção existente na relação entre os poderes Executivo e Legislativo, na medida em que o primeiro constantemente se vale do contingenciamento para cortar do orçamento recursos inseridos por emenda parlamentar, a fim de que a liberação desse dinheiro seja moeda de troca na aprovação de projetos de interesse e em outras espécies de chantagem para adquirir suporte político. Nada de incomum para o padrão brasileiro de fazer política: cria-se dificuldades para vender facilidades. Isso é típico do já exaurido sistema presidencialista de coalisão e mostra a sintonia, já falada antes, da crise política com a crise econômico-social.

Nada obstante, é um desvirtuamento da vontade popular, pois na maioria das vezes retira recursos de ações e investimentos públicos importantes ao bem-estar social, para permitir gastos maiores em setores não tão prioritários, mas de interesse político, sem que a sociedade tome conhecimento disso. Exemplos não faltam. Em 2014, ano das malfadadas pedaladas fiscais detectadas nas contas presidenciais, a dotação orçamentária referente à educação básica foi fixada em $\mathrm{R} \$ 32$ bilhões. O valor empenhado, porém, ficou em $\mathrm{R}$ \$ 29 bilhões, ou seja, um contingenciamento de $10 \%$ do valor original. Efetivamente aplicados, foram $\mathrm{R} \$ 26$ bilhões (20\% a menos). No mesmo exercício, as rubricas referentes à gestão e manutenção do Ministério da Educação tiveram previsão de R \$ 33,5 bilhōes, dos quais R \$ 32,5 foram efetivamente empenhados e aplicados. ${ }^{52}$

Foi no ano de 2015 que essa mazela sobressaiu com maior evidência. Em janeiro daquele ano, antes mesmo da retardatária aprovação da Lei Orçamentária Anual da União, o governo federal já havia realizado contingenciamento por meio do Decreto n. 8.389/2015, com base em disposições provisórias da LDO/2015, que havia sido publicada apenas cinco dias antes..$^{53}$

Assim, a norma jurídica que exige critérios objetivos e transparentes para o contingenciamento, entra para a coleção farta de dispositivos menosprezados na LRF.

A cultura do improviso e da gambiarra reflete-se ainda em outra forma de enfraquecer o planejamento orçamentário: a anulação de valores empenhados. $\mathrm{Na}$

52 MENDONÇA, Eduardo. O fetiche da despesa pública: sobre a proposta de limitação constitucional dos gastos públicos por vinte anos, apelidada de "PEC do Teto". Jota. Coluna Constituição e Sociedade. 22 de novembro de 2016. Disponível em: <http://jota.info/colunas/ constituicao-e-sociedade/o-fetiche-da-despesa-publica-22112016>. Acesso em: 22 nov. 2016.

53 Izaguirre, Mônica. Sai decreto que reduz limite de execução provisória do Orçamento. Valor Econômico. Disponível em: <http://www.valor.com.br/brasil/3850092/sai-decreto-que-reduz-limite-de-execucao-provisoria-do-orcamento>. Acesso em: 2 jan. 2017. 
iminente e já esperada falta de recursos, adiam-se pagamentos, anulando valores empenhados e pendurando-os na caixa dos restos a pagar, do qual já falamos antes e espero que não tenham esquecido.

$\mathrm{O}$ aumento exagerado desses restos a pagar, formando aquilo que chamamos atrás de orçamento-paralelo, além de maquiar o resultado das contas, dificulta em muito a capacidade de planejamento do governo, uma vez que essas despesas adiadas terão impacto no orçamento dos anos seguintes. A previsão e o resultado ficarão inevitavelmente comprometidos, assim como a gestão, por esse descontrole das finanças.

As mais prejudicadas por esses adiamentos são a saúde e a educação. Isso porque o limite constitucional mínimo de aplicação nesses elementos contabiliza os empenhos realizados nessas áreas, e não a aplicação efetiva por meio do pagamento. Assim, é comum que o governo empenhe o valor suficiente para o atingimento do limite previsto na $\mathrm{CRFB} / 88$, a fim de não sofrer as punições previstas na LRF e na Lei de Improbidade Administrativa, mas a despesa seja colocada em restos a pagar e fique para o ano seguinte.

A distância entre o orçado e o executado e, portanto, entre um planejamento sério e um planejamento precário, ainda pode ser aumentada por meio das realocações de verbas (remanejamento) ${ }^{54}$ e outras alterações promovidas na lei orçamentária no decorrer do exercício, como aquelas que, em 2014, 2015 e 2016, modificaram as metas de resultado primário da União, previstas na LDO, tornando-as completamente inúteis.

No caso do remanejamento, frente à explosão das despesas com pessoal, tem-se consolidado a transferência de valores das políticas sociais importantes para conter esse vazamento, lembrando um verdadeiro malabarismo com elefantes, semelhante ao livro de Jones Loftin e Todd Musig.

Diante desses fatores, é difícil que haja planejamento claro e sério. Como se basear em um indicador que não é confiável e que tem grandes chances de ser fantasioso? Tal dificuldade produz consequências graves no oferecimento de serviços públicos pelo Estado, vez que sem credibilidade das contas, não se faz política pública de qualidade. Destarte, o investimento público, que não é uma despesa obrigatória, como salários e aposentadorias, acaba sendo drasticamente reduzido e os serviços interrompidos no meio do caminho. É o que ocorre com as obras inacabadas, principal slogan da inépcia e da incompetência governamental em termos de planejamento.

54 O Legislativo costuma autorizar previamente, na própria LOA, a abertura de determinada quantia e em certas condições, de créditos suplementares (art. 7o, I, da Lei n. 4.320/64). 
Para fazer essa constatação lastimável, é simples: basta notar, primeiro, que no Brasil há cerca de cinco mil obras inacabadas ${ }^{55}$ e as perdas em decorrência dessas paralisações são gigantescas, podendo chegar a $\mathrm{R} \$ 1$ trilhão $0^{56} \mathrm{e}$, depois, passar os olhos no art. 45, da LRF, o qual estabelece que só serão incluídos novos projetos no orçamento após atendidos aqueles que ainda se encontram em andamento. Chega-se à conclusão de que talvez este dispositivo jamais tenha sido aplicado. Mais um para a coleção.

Não há como negar, portanto, que a causa mortis que deu origem ao cemitério de obras paralisadas no Brasil é a falta de planejamento, que reduziu drasticamente o investimento público. ${ }^{57}$

Dentro do hábito de superestimar as receitas, são incluídas no orçamento apenas fraçóes do que seria necessário para concluir um projeto plurianual, ou seja, que reclamaria mais do que um exercício para a sua finalização, como é o caso da maioria das obras públicas. Assim, basta que estejam previstos recursos para que o empreendimento seja iniciado, sem que haja garantias quanto a sua continuação. Falta dinheiro. Se fosse aplicado regularmente o art. 45, da LRF, esse parágrafo sequer estaria sendo escrito. $\mathrm{O}$ gestor, com dificuldades em pensar além de seu mandato, ganha os créditos pela inauguração, mas deixa, muitas vezes, um zoológico de elefantes brancos espalhados pela região. O problema já não é mais seu.

Em outros países, a autorização legislativa para a inclusão de projetos que demandem mais de um exercício deve ocorrer pelo valor total do projeto, evitando esses contratempos.

Daí decorre que as principais irregularidades que justificam a paralisação de obras brasileiras são aquelas que têm vínculo com a fase inicial do procedimento, ou seja, a fase de planejamento. No relatório anual de fiscalização de obras públicas (Fiscobrás), elaborado pelo TCU, ${ }^{58}$ no final de 2017, das 94 obras avaliadas,

55 PEREIRA, Renée. Brasil tem cerca de 5 mil obras paradas. O Estado de S.Paulo. Disponível em: <http://economia.estadao.com.br/noticias/geral,brasil-tem-cerca-de-5-mil-obras-paradas,1887811>. Acesso em: 20 out. 2016.

56 BRASIL. Senado Federal. Perdas com obras inacabadas podem chegar a 1 trilhão de reais. Disponível em: <http://www12.senado.leg.br/noticias/materias/2016/12/14/perdas-com-obras-inacabadas-podem-chegar-a-r-1-trilhao>. Acesso em: 15 dez. 2016.

57 ORAIR, Rodrigo. Investimento público no Brasil: trajetória e relaçōes com o regime fiscal. Instituto de Pesquisa Econômica Aplicada (IPEA). Seminário Internacional/IPEA. Disponível em: <http://www.ipea.gov.br/agencia/images/stories/PDFs/160311_orair_2016_03_10. pdf>. Acesso em: 9 jan. 2017.

58 TCU, Acórdão n. 2.449/2017, Plenário, Rel. Min. Vital do Rêgo, sessão extraordinária do dia 08.11.2017. 
contempladas na LOA/2017 do governo federal, 72 (76\%) detém irregularidades graves. Dos 327 achados de auditoria apontados nestas obras, 36\% dizem respeito a falhas na fase de planejamento. Índice este que seria ainda maior se fôssemos mais rigorosos e considerássemos como esse defeito influencia indiretamente nas demais irregularidades.

Este é um problema também de comunicação. Sequer há um cadastro efetivo que dê transparência às obras públicas executadas com recursos federais, o que já foi determinado pelo TCU em diversas oportunidades, dificultando o levantamento atualizado, inclusive pela própria administração pública federal, das obras que estão paralisadas e por quais motivos. ${ }^{59}$

Já afirmei em obra anterior (O Ovo da Serpente, Editora Fórum, 2015) e posso reiterar que as obras paralisadas andam de mãos dadas com a corrupção. Elas são amigas e dificilmente aparecem isoladas.

Todas as falhas, aqui, apontadas não existem isoladamente. Elas têm em seu DNA a deficiência do próprio controle do planejamento. O método de fiscalização atual, por se ater apenas a critérios de conformidade com normas jurídicas, sem dar a devida atenção aos resultados efetivamente produzidos e à consonância deles com o que foi planejado, acaba tornando-se negligente com certas práticas. Os próprios tribunais de contas ainda não consolidaram a prática de fiscalizar a performance e, por conseguinte, o planejamento dos gastos, bastando-se no exame formalístico das contas, num viés cartorário.

Ocorre que gasto sem planejamento é sinônimo de gasto sem qualidade.

$\mathrm{Na}$ maioria das vezes, a preocupação em arrecadar mais, para gastar mais, desloca a atenção de questões relevantes, que acabam sendo esquecidas: como gastar melhor? O uso eficiente dos recursos (limitados) do Estado, quando da construção do planejamento, é uma questão tão importante quanto olvidada, sobretudo no Brasil, onde os serviços públicos não encontram equivalência com o que se gasta para financiá-los.

O Ministério do Planejamento, Orçamento e Gestão recentemente atualizou algumas análises de gastos governamentais brasileiros, comparando-os aos de outros países. Chegou as seguintes conclusões: o Brasil gasta, por pessoa na área da saúde, três vezes mais que a China, mas tem indicadores semelhantes de mortalidade infantil e expectativa de vida. ${ }^{60} \mathrm{Na}$ educação, há a reivindicação recorrente

59 Acórdão n. 2.155/2015-TCU-Plenário, Rel. Min. Vital do Rêgo. Sessão de 26.08.2015.

60 BLIACHERIENE, Ana Carla. Controle da eficiência do gasto orçamentário. Belo Horizonte: Fórum, 2016, p. 19. 
para realizar mais investimentos, no entanto, o último relatório (2015) do Programa Internacional de Avaliação de Estudantes (Pisa), da OCDE, mostra que o país triplicou o orçamento com educação a partir de 2003. Ainda assim, não houve melhoras significativas nos resultados do exame, tendo o país piorado desde a última avaliação, em 2012, passando a ocupar posição inferior em comparação com países que gastam menos, como Colômbia, México e Peru. ${ }^{61}$ Ademais, com apenas $7 \%$ da população tendo mais de 65 anos, gasta-se $41,5 \%$ do orçamento (13\% do PIB) com aposentadorias e pensões.

Os dados revelam duas coisas: primeiro, que o Brasil gasta mal e, segundo, que gasta errado. Nesses casos, o ditado é certeiro, pois quem paga mal, paga duas vezes. Por isso as despesas aumentam continuamente, porém o resultado não é percebido. Espera-se que a aplicação crescente de recursos em saúde e educação irão resolver naturalmente as carências nessas áreas. Excesso de aspirina não irá curá-los.

A preocupação deve ser pela qualidade, além da quantidade.

Não se trata de ter mais ou menos recursos. Mais do que isso, o Estado necessita de eficiência, o que reclama, acima de tudo, um planejamento com horizontes bem mais distantes do que as políticas imediatistas que são geralmente adotadas. Falta incentivos; falta o Conselho de Gestão Fiscal, do art. 67 da LRF que nunca foi aplicado (já perderam a conta da coleção?); falta a Lei de Qualidade Fiscal, que amargura anos nas gavetas do legislativo brasileiro. A análise dessas soluções fica, entretanto, para outro capítulo mais à frente.

\section{Segundo eixo: engajamento cívico - uma ausência dolorosa}

Para iniciar esse tópico de suma importância, recorro ao poema de Fernando Pessoa, em "anjos ou deuses":

Nossa vontade e o nosso pensamento

São as mãos pelas quais outros nos guiam

Para onde eles querem

E nós não desejamos ${ }^{62}$

${ }^{61}$ GUIMARÃES, Lígia. OCDE: Brasil gasta mais com educação, mas aprendizado não melhora. Valor Econômico. Disponível em: <http://www.valor.com.br/brasil/4796963/ocde-brasil-gasta-mais-com-educacao-mas-aprendizado-nao-melhora>. Acesso em: 2 jan. 2017.

62 REIS, Odes de Ricardo. Fernando Pessoa. Notas de João Gaspar Simões e Luiz de Montalvor. Lisboa: Ática, 1946. 
- Finanças públicas: travessia entre o passado e o futuro

Uma pequena alteração é suficiente para adequar o fragmento poético a nossa matéria, senão vejamos: "Nossa vontade e o nosso orçamento / São as mãos pelas quais outros nos guiam / Para onde eles querem / E nós não desejamos". Atualmente, o orçamento é exatamente isso: uma mão pela qual os governantes nos levam para aonde lhes interessa, sem que ouça os anseios da população. $\mathrm{O}$ cidadão é muito mais um leitor passivo, do que um editor.

Por isso, é comum ouvir que o orçamento brasileiro é burocrático, porém não democrático. Porque o substantivo da democracia é a participação. Quem diz democracia diz, no mesmo passo, presença do povo nas decisões do governo. Sem isso, o regime democrático é quimera, é ilusão, é promessa sem correspondência na realidade. ${ }^{63}$ Apesar da função importantíssima que o orçamento cumpre na vida de todos, a participação na sua confecção, execução e controle, ainda é extremamente limitada.

No entanto, esse déficit de engajamento e controle social não se limita ao aspecto orçamentário, se espalhando também na esfera política. São duas faces de uma mesma moeda, uma vez que somente participando é possível controlar. ${ }^{64}$

A propósito, pesquisadores têm sugerido que quando as pessoas tomam parte nas deliberaçôes que afetem seus interesses, elas tornam-se mais preparadas para avaliar o desempenho dos agentes e os resultados das políticas públicas, tanto em nível local, como em nível nacional.

O canal que aproxima as questóes de governo aos interesses do povo é uma via de mão dupla. De lá para cá, existe a obrigação do poder público em abrir caminhos e promover incentivos para que a sociedade se manifeste nos processos de tomada de decisões - abertura governamental. De cá para lá, deve haver o interesse cívico genuíno dos cidadãos em fazer com que sua voz ecoe nos setores governamentais, para que as políticas adotadas carreguem o seu DNA.

Percebe-se, no entanto, que atualmente essas duas vias estão obstruídas, estreitando a ponte pela qual se comunicam sociedade e estado. Tanto são escassas as medidas do governo em ordem a facilitar e incentivar que as pessoas sejam consultadas sobre seus interesses e necessidades, a exemplo do que fez a administração de Chicago (EUA), ao espalhar outdoors pela cidade com a seguinte pergunta: "Como

63 BONAVIDES, Paulo. Teoria constitucional da democracia participativa: por um direito constitucional de luta e resistência, por uma nova hermenêutica, por uma repolitização da legitimidade. São Paulo: Malheiros, 2001, p. 283.

64 PATEMAN, Carole. Participation and democratic theory. 1st. ed., 5th reprinting. Cambridge: Cambridge University Press, 1976. 
você gastaria US\$ 1 milhão de dólares?”, ${ }^{65}$ para chamar a atenção a respeito do orçamento participativo de 2014. Como ainda é marcante a indiferença e, por vezes, a relutância dos cidadãos em reivindicar a sua inserção na agenda política do município ou do estado.

Dentro desse contexto, o déficit de confiança nas instituições da democracia que marca os nossos dias tem a mesma - senão maior - importância do que o déficit nas contas públicas. O poder emana do povo, conforme assinala a Constituição, mas para onde ele vai?

Agora que o povo possui uma voz mais audível do que nunca, seja pelas redes sociais, pelos aplicativos, startups, seja pelas manifestações de rua, não há desculpas para não o escutar com atenção. Qualquer governo será muito pequeno hoje se não se alimentar das ideias de seus governados.

Do mesmo modo, não é o bastante exercer a cidadania somente nas urnas eletrônicas de tempos em tempos e não querer continuar sujando as mãos com democracia permanentemente. A escolha de quem vai gerenciar os recursos públicos é essencial, mas tão imprescindível quanto é a eleição de como o dinheiro será gerido, além da avaliação posterior do dispêndio. Em outras palavras: a democracia não representa apenas um regime de governo ou as regras do jogo político, mas um estilo de vida, de modo que a cidadania deve ser cotidiana, não apenas quando algo nos incomoda.

Observa-se atualmente uma quase-falência do sistema de representação política tradicionalmente instalado no Brasil e em outras democracias liberais modernas. Os escândalos de corrupção cada vez mais frequentes e a falta de identificação dos eleitores para com os eleitos, incutiu na população uma desconfiança generalizada, quase niilista, em relação aos políticos e à forma de fazer política. O brado "não me representa" tornou-se corriqueiro e simboliza essa descrença. Por outro lado, percebe-se que, para os representantes políticos, há uma banalização da cidadania, que deixou de ser tão crucial quanto a Constituição quis que ela fosse.

Entre as questôes de primeira ordem ao bem-estar da sociedade, o orçamento público é a testemunha mais clara dessa triste realidade. Sua elaboração marcadamente burocrática, promovida no interior de gabinetes inacessíveis, e a execução discricionária da lei orçamentária faz com que as escolhas alocativas, na maioria das vezes, ignora as prioridades reais do povo.

65 PAPE, Madeleine; LERNER, Josh. Budgeting for Equity: how can participatory budgeting advance equity in the United States? Journal of Public Deliberation, v. 12: Iss. 2, Article 9, 2016. Disponível em: <http://www.publicdeliberation.net/cgi/viewcontent.cgi?article=1435 \&context=jpd>. Acesso em: 7 jan. 2017. 
Justamente por isso, há uma demanda forte e atual para que as formas tradicionais (desgastadas) de democracia representativa sejam acompanhadas, ou até mesmo substituídas, por mecanismos de democracia direta, onde o cidadão possa atuar sem intermediações. A ideia de democracia participativa surge, portanto, das próprias deficiências que a representação política foi desvelando com o tempo e que hoje estão em evidência no Brasil. O descontrole dos gestores e a discrepância entre o que os brasileiros-contribuintes pagam de tributos e a contrapartida do Estado por meio de serviços precários ajudaram a intensificar esse quadro.

Nesse confronto entre representação e participação, crescem as vias de atuação e controle do cidadão nas decisões políticas; formas complementares ao sistema representativo, que emergem deste sentimento de desconfiança, para as quais Pierre Rosanvallón deu a seguinte denominação: contrademocracia ${ }^{66}$ Existem vários instrumentos institucionalizados e expressos na Constituição, com fundamento no parágrafo único do art. $1^{\circ}$ ("todo poder emana do povo"), que permitem essa ação cidadã: o voto (art. 14), o plebiscito (art. 14, I), o referendo (art. 14, II), a iniciativa popular de lei federal, estadual e municipal (arts. 14, III, 61, $\$ 2^{\circ}, 27, \$ 4^{\circ}$ e 29 , XIII), a ação popular (art. 50, LXXIII), as contas municipais à disposição por sessenta dias para fiscalização dos cidadãos (art. 31, $\$ 3^{\circ}$ ), a participação em audiências (art. 58, II), a legitimidade de qualquer cidadão para denunciar irregularidades ou ilegalidades perante o Tribunal de Contas (art. 74, $\$ 2^{\circ}$ ), o assento em órgãos deliberativos da administração (arts. 89 e 103-B), o júri popular (art. 5, XXXVIII) e o orçamento participativo (art. 29, XII). Têm crescido, ainda, modos de participação e controle social não institucionalizados, isto é, não convencionais, mas que também detém importância significativa no encurtamento da distância entres sociedade e administração pública: observatórios sociais, manifestações populares, ONGs, advocacy-groups etc.

$\mathrm{O}$ fato de que, numa perspectiva geral defendida por pesquisadores do Banco Mundial, ${ }^{67}$ a corrupção e os desvios públicos estão associados com uma alocação particularista (patrimonialista) de recursos públicos, ou seja, com a institucionalização de privilégios injustificados numa sociedade igualitária, a questão orçamentária ganha destaque na análise do controle social. Soma-se ainda a circunstância de que é através do orçamento que se realizam os direitos fundamentais, convertendo os artigos de lei elencados no papel em realidade constitucional.

66 ROSANVALLON, Pierre. La contrademocracía: la política en la era de la desconfianza. Buenos Aires: Manantial, 2015.

67 MUNGIU-PIPPDI, Alina. The quest for good governance: how societies develop control of corruption. Cambridge University Press, 2015. 
$\mathrm{Na}$ formação do planejamento orçamentário, a participação direta é especialmente relevante. Os problemas da sociedade moderna (de risco) detêm uma complexidade que só pode ser enfrentada por decisões plurais, que considerem os vários interesses existentes. Fato que a burocracia não consegue alcançar, tampouco pretende resolver. O gestor público, portanto, há que buscar legitimar as suas decisóes inserindo o povo na discussão. É triste constatar, no entanto, que o orçamento público ainda é tratado com grande indiferença pela sociedade. É ruim que seja assim. A falta de engajamento popular neste âmbito permite que as decisóes políticas ali tomadas sejam capturadas por interesses políticos.

A lei orçamentária documenta a vida financeira do ente e o conjunto de escolhas políticas da gestão, de modo que o cidadão não deve ser somente o leitor, mas também editor desse documento. Que as pessoas debatam, decidam e acompanhem como está sendo gasto o seu próprio dinheiro soa como algo óbvio, que dispensa maiores explicações, mas implementar essa ideia de modo eficiente ainda é um desafio a ser superado.

Não custa lembrar que ao abrir as portas da administração para que o cidadão se manifeste e interfira, os governantes não estão prestando-lhe um favor, ou manifestando um saldo eleitoral, senão efetivando um dever de legitimação democrática. A estética dessa obrigação, na realidade, é bem simples e Paulo Bonavides nos ajuda a entendê-la melhor: governar é legislar - elaborar o orçamento é uma das principais formas de fazê-lo, já que é a segunda lei mais importante da república, atrás apenas da Constituição. Em se tratando, contudo, de democracia, legisla quem tem legitimidade. E legitimidade quem possui é o povo. Conclusão: não pode se dar sem ele. ${ }^{68}$

O poder público, nas três esferas de governo, anda a passos lentos no dever de ampliação da participação popular dentro do processo orçamentário, para encurtar a distância que vai das finanças à realidade, da democracia à sociedade, do governo à cidadania.

De um modo geral, é possível encontrar algumas experiências em termos de participação orçamentária, mais concentradas na esfera municipal. Porto Alegre, em 1989, deu o pontapé inicial às medidas de inclusão com o orçamento participativo (OP), posteriormente copiado mundo afora. Atualmente, mais de 300 municípios adotam esse procedimento, embora, na maioria dos casos, seja realizado como mera formalidade.

68 BONAVIDES, Paulo. Teoria constitucional da democracia participativa: por um direito de luta e resistência, por um, p. 345 . 
- Finanças públicas: travessia entre o passado e o futuro

Essa inclusão deveria ocorrer em todas as fases do ciclo: formação dos projetos de PPA, LDO e LOA, execução orçamentária e controle, mas principalmente na primeira, que é crucial ao planejamento e a eficiência da gestão pública.

A legislação é farta na previsão dos instrumentos responsáveis por viabilizar essa inclusão da sociedade no orçamento. ${ }^{69}$ Mesmo assim, e ainda que estes mecanismos encontrem-se implementados em diversos estados e municípios, eles não funcionam adequadamente. A ineficiência dos métodos de participação na alocação dos recursos coletivos enfraquece a responsividade dos agentes eleitos, isto é, a sua capacidade de fornecer respostas às necessidades da população, além de fragilizar a responsabilidade sobre essas autoridades, na medida em que possíveis deturpações realizam-se à revelia da sociedade.

$\mathrm{Na}$ medida em que se tornou politicamente vantajoso afirmar que estão sendo efetivados esses instrumentos de participação popular, o "parecer/aparecer" passou a ter muito mais valor do que o "ser/conteúdo". Assim, é comum que gestores se utilizem de audiências públicas, conselhos e orçamentos participativos como formalidades para justificar os seus atos e dar-lhes um plus de legitimidade, sem, contudo, que a opinião popular surta qualquer efeito prático. A participação como mera consulta é e será perfumaria sem essência alguma.

Tal constatação serve tanto à união, como aos estados e municípios brasileiros. No entanto, quanto a esta última esfera, as formas de democratização que vimos acima deveriam reservar maior importância, por ser aonde as decisões políticas são mais próximas e os efeitos do orçamento sentidos com maior força. Soma-se ainda a crescente importância das cidades na estrutura da federação, sobretudo pelo aumento do nível de recursos que dispõem, a partir das transferências recebidas pela União, e dos serviços públicos que prestam. ${ }^{70}$

69 Lei n. 10.527/2001. Art. 40 (...), $\$ 3^{\circ}$ “Os instrumentos previstos neste artigo que demandam dispêndio de recursos por parte do Poder Público municipal devem ser objeto de controle social garantida a participação de comunidades, movimentos e entidades da sociedade civil". Além deste dispositivo, estão previstos os seguintes instrumentos: audiências públicas (art. 90, $\$ 4^{\circ}$ e 48, da LRF; art. 39, da Lei n. 8.666/93; art. 29, 31, 32 e 34, da Lei n. 9.784/99; art. 40, $\$ 4^{\circ}$, I, da Lei n. 10.527/2001); orçamento participativo (art. 29, XII e 37, \$3º, da CF/88; art. 44, da Lei n. 10.527/2001); e órgãos colegiados de políticas públicas (arts. 29, XII, 198, III, 204, II, 206, VI e 227, $₫ 1^{\circ}$ da CF/88 e art. 43, I, da Lei n. 10.527/2001).

70 "Na perspectiva histórica mais longa, apenas a esfera local de governo ganhou (...) participação relativa na receita tributária. (...) É até possível que mais do que descentralização, o Brasil tenha experimentado uma municipalização da sua receita”. AFONSO, José Roberto R. Sistema tributário, o Brasil ainda voltará a ter um? In: ALMEIDA, Mansueto; SALTO, Felipe (Coord.). Finanças públicas: da contabilidade criativa ao resgate da credibilidade. 2. ed. Rio de Janeiro: Record, 2016, p. 162. 
Ao decidir o que fazer com o dinheiro público, sempre limitado para a administração, escolhas trágicas devem ser feitas e as alocações particularistas evitadas. Seria ótimo se houvesse recursos para atender a tudo e a todos. Lewis Carroll nem precisa ter escrito Alice. Mas a realidade é outra, ela exige que sejam eleitas prioridades e que estas se aproximem ao máximo dos anseios da sociedade, os quais só poderão ser traduzidos se forem ouvidos.

\section{Orçamento participativo: chegada a hora}

Em um dos seus mais famosos pronunciamentos, Benjamin Constant opõe a liberdade dos antigos à liberdade dos modernos. $\mathrm{Na}$ antiguidade, afirma: "a parte que cada um tinha da soberania nacional não era, como em nossos dias, uma suposição abstrata. A vontade de cada um tinha uma influência real: o exercício dessa vontade era um prazer vivo e repetido". Nos tempos modernos, entretanto, assinala que: "perdido na multidão, o indivíduo não percebe quase nunca a influência que exerce. Não constata a seus próprios olhos a sua cooperação" ${ }^{71}$

Quanto menos conhece e se sente integrado na alocação dos recursos públicos, menos confiança tem o cidadão para contribuir com o pagamento de tributos. Desde que o gasto público passou a ser controlado por intermédio do orçamento, o maior desafio é que as leis orçamentárias espelhem aquilo que a sociedade espera que o poder público faça com o dinheiro pertencente a ela.

$\mathrm{O}$ orçamento participativo se insere nesse contexto como um dos instrumentais capazes de superar esse desafio e dar substrato social ao gasto público.

Considerado uma forma de "civismo revolucionário em ação", pelo jornal americano New York Times, o orçamento participativo se refere ao processo pelo qual os cidadãos ajudam a decidir como alocar recursos públicos, dando-lhes - ou devolvendo-lhes - o poder de identificar as necessidades da comunidade para, trabalhando em conjunto com as autoridades eleitas, votar de que forma será gasto o dinheiro público a partir da proposta orçamentária. Tem o privilégio de ser, a um só tempo, mecanismo de transparência, planejamento, controle, igualdade social e educação.

Isso porque, sendo chamadas a cooperar na formulação do orçamento, as pessoas tomam conhecimento de como os recursos estão sendo dispendidos, dando transparência à ação pública. Ao mesmo tempo, permite-se que elas acompanhem e avaliem os projetos e obras que foram objeto de debate e que fazem parte do

71 CONSTANT, Benjamin. Da liberdade dos antigos comparada à dos modernos. Discurso pronunciado no Athéneé Royal de Paris, 1819, p. 6-7. 
planejamento do ente, controlando a execução e a programação das despesas e se elas estão atendendo às necessidades mais prioritárias levantadas no OP. Além disso, o orçamento participativo possibilita a inclusão de grupos tradicionalmente marginalizados, alijados do processo político, permitindo realizar a igualdade social ao distribuir de maneira justa mais recursos àqueles que mais precisam. Ao canalizar os debates em torno da alocação de recursos, serve ainda como instrumento pedagógico, dado que incentiva o cidadão a continuar e ampliar a participação para outros setores políticos além do orçamento.

Todos esses efeitos convergem para a redução das práticas de corrupção e de irrealismo orçamentário, como as que vimos no tópico antecedente.

Ao Brasil sempre se reconheceu a especialidade em ser o berço de situações inusitadas e aberrações jurídicas, geralmente apelidadas de jabuticabas ou jabutis. Fugindo desse padrão desfavorável, foi em Porto Alegre - RS, em 1989, que se concebeu o orçamento participativo, com as seguintes diretrizes: a) integração da sociedade na formação das decisões políticas; b) redução da corrupção através da transparência financeira; c) desenvolvimento na prestação de serviços; d) renovação moral do processo político, onde os cidadãos são inseridos ativamente no governo. Aliás, a experiência porto-alegrense é mundialmente reconhecida como pioneira neste sentido, mostrando que também sabemos utilizar a criatividade de forma positiva, e não só contábil.72

Ali, os cidadãos passaram a discutir diretamente a peça orçamentária em encontros e assembleias. A primeira reunião ocorreu no Sindicato dos Metalúrgicos e contou com 200 participantes. Em 1998, o orçamento participativo já abrangia 13 mil interessados ao longo do procedimento. Esse modelo foi implementado posteriormente em Belo Horizonte e Recife, onde desenvolveram-se outras inovações ao método inicial. ${ }^{73} \mathrm{O}$ OP logo espalhou-se em outros municípios pelo país. Um levantamento da Rede Brasileira de Orçamentos, de 2013, aponta 355 experiências em andamento.

72 Que reste-t-il de l'expérience pionnière de Porto Alegre? Les défis de la démocratie participative. Le Monde Ddiplomatique. Disponível em: <https://www.monde-diplomatique.fr/2011/10/A/21113 >. Acesso em: 10 jan. 2017; e 4 Council Members, each with \$1 million, will let public decide how it's spent. New York Times. Disponível em: <http://www.nytimes. com/2011/09/14/nyregion/4-on-ny-city-council-will-let-public-decide-some-spending. html>. Acesso em: 11 jan. 2017.

73 PORTO DE OLIVEIRA, Osmany. Embaixadores da participação: a difusão internacional do Orçamento Participativo a partir do Brasil. 2013. 292 f. Tese (Doutorado) - Departamento de Ciência Política, Faculdade de Filosofia, Letras e Ciências Humanas, Universidade de São Paulo. São Paulo, 2013. 
Não demorou para que esse promissor instituto de participação direta fosse disseminado pelo mundo. A globalização do orçamento participativo foi rápida e intensa. Em 2010, relatório da Agência Alemã de Cooperação (GIZ) ${ }^{74}$ contou cerca de 1500 experiências de OP no mundo. Em 2013, esse número subiu para mais de $2.800 .^{75}$

Tomando inspiração das experiências brasileiras, metrópoles de todo mundo hoje possuem orçamentos participativos.

Nos Estados Unidos, o processo teve início em 2008, no 49º distrito de Chicago, onde o vereador Joe Moore utilizou 1 milhão de dólares de seu orçamento discricionário ${ }^{76}$ para que a população local decidisse para quais políticas pretendiam destiná-lo. Em Nova York, o OP chegou somente em 2011, também pela iniciativa de vereadores em se valer do seu fundo discricionário para promover o debate orçamentário. O número de participantes e dólares que forma alocados dessa forma nos EUA mais do que dobrou desde 2011. Em 2016, percebe-se que o processo continua em vertiginoso crescimento, incluindo cinco experiências em distritos de Chicago e em outras cidades (p.ex.: Eugene, Vellajo, Sacramento). De acordo com o Projeto de Desenvolvimento Comunitário do Centro de Justiça Urbana americano, o ciclo 2014-2015 de OP em Nova York foi capaz de reunir 58.095 pessoas e alocar 39 milhóes de dólares. ${ }^{77}$

Já na França, em 2014, a prefeita da capital Paris, Anne Hidalgo, seguindo casos já consolidados em Saint-Dennis desde 2000, implementou a primeira experiência de OP (Paris Budget Participatif) na cidade, submetendo 20 milhões de euros aos projetos da sociedade. No ano de 2016, essa parcela do orçamento chegou a 100 milhões de euros e abrangeu projetos de construção de abrigos para moradores de rua e um campo para refugiados. ${ }^{78}$

74 SINTOMER, Yves; CARSTEN Herzberg; ALLEGRETTI, Giovanni. Learning from the south: participatory budgeting worldwide - an invitation to global corporation. Capacity Building International. GIZ - Allemagne, 2010.

75 Idem, p. 73.

76 Em certos municípios americanos, os vereadores dispõem de um fundo discricionário no orçamento para que possam utilizar durante o mandato, semelhante, de certa forma, às emendas parlamentares previstas no ordenamento jurídico brasileiro.

77 A people's budget: a research and evaluation report on participatory budgeting in New York City. Key Research Findings. October 20, 2015. Disponível em: <https://cdp.urbanjustice.org/ sites/default/files/CDP.WEB.doc_Report_PBNYC_cycle4findings_20151021.pdf>. Acesso em: 11 jan. 2017.

78 Paris Budget Participatif. Projets déposés en 2016. Disponível em: <https://budgetparticipatif. paris.fr/bp/jsp/site/Portal.jsp?page=search-solr\&conf=list_idees $>$. Acesso em: 13 jan. 2017. 
O Governo de Portugal reservou 3 milhões de euros do ano de 2017 para a implementação do orçamento participativo da União, algo inédito, vez que não há registros de utilização desse método em âmbito nacional. Com efeito, limitou-se a participação a quatro áreas específicas de políticas públicas: cultura, agricultura, ciência e formação de adultos. ${ }^{79}$

Outros países foram além, elevando o orçamento participativo à condição de política estatal, com a promulgação de lei nacional específica, como o Peru, ou ainda o inserindo no texto constitucional, como o Equador.

O propósito de abordar todas essas experiências ao redor do mundo e como o instituto tem evoluído de variadas formas, todavia, não é somente para mostrar que o Brasil foi imprescindível neste processo, mas que o orçamento participativo tem recebido mais atenção lá fora do que aqui dentro. Paradoxalmente, não obstante o OP tenha filiação brasileira, os pais adotivos parecem dar mais valor ao "filho".

Hoje, verifica-se no Brasil a proliferação de práticas que se intitulam orçamentos participativos, mas que, na realidade, são meros procedimentos de consulta pública sobre uma parcela do investimento público. Na maioria dos casos, o poder público se limita a convidar o cidadão para palestras ou assembleias nas quais este mais ouve do que fala, e quando lhe é possível formular projetos, o governo reserva para si o poder de decidir quais dessas propostas irá ou não inserir no orçamento. Participação só no papel.

Inobstante a existência de algumas experiências que mantiveram o grau de eficiência dos OP primitivos em Porto Alegre e Belo Horizonte, o modelo que ora prevalece revela perdas significativas em termos de qualidade, que apontam para uma participação orçamentária precária, funcionando como um anteparo de legitimidade disfarçada para o atendimento de interesses políticos e econômicos do gestor público.

No sistema jurídico nacional, vários dispositivos cuidam de estabelecer o dever de inserir o cidadão no processo alocativo. $\mathrm{O}$ art. 48, da LRF, determina a participação por meio de audiências durante a etapa de elaboração das peças de planejamento (PPA, LDO e LOA).

Atualmente, vários dispositivos cuidam de estabelecer o dever de inserir o cidadão no processo de confecção orçamentária. O art. 48, da LRF, determina a participação em caráter nacional por meio de audiências durante a elaboração das

79 Orçamento participativo: queremos convocar as pessoas a pensar o país. Disponível em: $<$ http://www.rtp.pt/noticias/politica/orcamento-participativo-queremos-convocar-as-pessoas-a-pensar-o-pais_v974797>. Acesso em: 11 jan. 2017. 
peças de planejamento (PPA, LDO e LOA). A própria Constituição segue este rumo ao dispor no art. 29, XII, que os municípios devem promover a cooperação com associações representativas em seu planejamento. No entanto, é a Lei n. 10.527/2001 (Estatuto da Cidade), que serve como parâmetro jurídico ao orçamento participativo nos municípios brasileiros, uma vez que estabelece que a gestão orçamentária deverá incluir debates sobre o PPA, a LDO e a LOA, prevendo ainda que tal procedimento é condição necessária à aprovação da norma nas Câmaras Municipais (art. 44). Esta última, fazendo referência específica à esfera municipal, ressalta o aspecto da proximidade, afinal, o cidadão não vive na União nem no estado, mas no município - como não cansava de enfatizar Franco Montoro.

Assim, a implementação genuína de um procedimento efetivo de participação no orçamento público ainda tem que superar desafios que remanescem no sistema político, que, por ter regras e costumes próprios, dos quais é difícil se desvencilhar, acaba contaminando instrumentos potencialmente positivos à gestão pública democrática.

Poder-se-ia apontar, como exemplos, a forma incrementalista que ainda impera na alocação de recursos, repetindo gastos a despeito da análise crítica e estudada sobre as necessidades locais, ou a conduta cartorária dos parlamentos, que se limitam a atender bases eleitorais e determinados grupos de interesse, ao invés de debater seriamente o planejamento proposto pelo Poder Executivo.

Além disso, outros impasses permeiam o próprio processo de implementação e funcionamento do orçamento participativo, que atravancam o desempenho ótimo dessa ferramenta.

Os seguintes obstáculos podem ser compilados em relação à implantação da OP na política estatal: a) na maioria das vezes, a realização do OP fica condicionado à vontade política do gestor, que mantém resistência em abdicar do controle que exerce sobre a elaboração e execução orçamentária, uma vez que a abertura ao povo implicaria perder a possibilidade de destinar parcela do orçamento à concessão de privilégios e à manutenção de interesses políticos; b) deficiência no processo de comunicação, com a falta de compromisso dos agentes em transmitir informações e promover o engajamento dos cidadãos para participar; c) ausência de lei nacional específica que unifique o tratamento do orçamento participativo no Brasil, esclarecendo métodos, procedimentos e consequências para a não realização; d) a contaminação do processo pelo excesso de burocracia, fator que desestimula a participação; e) o inchaço do orçamento brasileiro com despesas obrigatórias, carimbadas e com destino certo, havendo cada vez menos espaço para investimentos públicos e despesas suscetíveis de debate no âmbito da alocação orçamentária. 
No tocante ao funcionamento do OP, seriam dificuldades exemplares: a) ausência de um sistema que canalize as propostas prioritárias, sem que isso implique no estreitamento da possibilidade de manifestação pública, haja vista o propósito de incluir na discussão as classes mais abastadas; b) a dinâmica é frequentemente capturada por grupos desconectados dos reais interesses da população; c) indivíduos que detém maior nível de informação e conhecimento sobre as regras podem obter vantagens para si ou para determinado setor, em detrimento daqueles que não estão habituados a participar, o que acaba por prejudicar o propósito redistributivo do OP, uma vez que isola as demandas em grupos elitizados; d) a utilização do procedimento como mera consulta pública, sem vinculação das instâncias decisórias àquilo que foi "discutido" no âmbito do orçamento participativo.

Todos esses desafios práticos colocam em risco a efetividade do engajamento orçamentário como ferramenta de gestão compartilhada da coisa pública, convertendo-o em mero formalismo ou coleta de opinião pública travestida de exercício da cidadania. Não adianta que as propostas de alocação produzidas pela sociedade civil não tenham influência nos planos ou leis orçamentárias, sob pena de que o planejamento perca todo o seu potencial democrático.

Existe, portanto, um extenso caminho a ser percorrido para que o orçamento participativo - tomado aqui apenas como exemplo, e as demais instâncias de deliberação política que existem apenas na letra da lei brasileira, sejam afastadas dos vícios comuns da política, que ameaçam a sua eficácia e tendem a aprofundar o fosso entre a vontade popular e as políticas públicas.

Além do mais, é ingênuo imaginar que algumas reuniōes e meia dúzia de palestras servirão para inserir as digitais da sociedade em um orçamento acostumado a repartir fatias com o clientelismo e a patronagem. O engajamento cívico exige mais do que isso para superarmos o mal crônico das alocações particularistas que alimentam os desvios públicos.

A transformação tecnológica do mundo, simbolizada pela revolução digital e difusão das mídias sociais, não só pode como deveria ter o condão de introduzir uma maior abertura do processo orçamentário à sociedade, associando a participação ao uso dos novos mecanismos de interação, como as redes sociais e aplicativos de celulares. Não há desculpa para obstruir a opinião pública quando se observa que poucos cliques podem tornar o estado ciente de como o cidadão pretende que seja gasto o seu dinheiro. Na África, onde os níveis de desenvolvimento socioeconômico e, portanto, de inclusão digital, são, tradicionalmente, menores do que no resto do mundo, já há casos que representam essa realidade. Na região de Kivu do Sul, na República Democrática do Congo, por exemplo, um projeto de orçamento 
participativo, financiado pelo Banco Mundial, inseriu a participação por meio de mensagens via SMS. ${ }^{80}$ Desta forma, permitiu-se ao cidadão votar em prioridades de infraestrutura e vigiar o processo orçamentário pelo telefone celular.

Não ultrapassaremos o expeço lamaçal da imoralidade e da ineficiência brasileiras se as pessoas não forem convocadas a pensar o país e transformar este estado de coisas, começando pelas finanças do seu município. O modo como fazemos nossa democracia funcionar não diz respeito somente à mudança de nossos políticos ou das políticas que eles implementam, mas à mudança de nós mesmos, de observadores apáticos da realidade para cidadãos ativos e engajados.

\section{Audiências Públicas: inclusão}

Gostaria de retomar a pergunta formulada no início desse tópico para fazer uma provocação. Todo poder emana do povo, mas para onde ele vai? Iria ele somente até a confirmação do voto perante a urna de quatro em quatro anos? Ou estender-se-ia mais um pouco para alcançar a decisão quanto à alocação de recursos públicos através do orçamento participativo e, daí, teria por encerrado o seu caminho? Nenhuma das duas hipóteses.

O poder que emana do povo percorre todas as decisões do poder público para conferir-lhes legitimidade e torná-las transparentes. Ele é a sombra da vida política, acompanhando-a permanentemente. Por isso, o sufrágio como modelo participativo não é suficiente, tampouco o orçamento participativo. A voz do cidadão precisa ecoar, ir mais longe, ainda que ele não precise falar mais alto.

É fundamental, portanto, que se dê mais atenção às audiências públicas, que representam justamente essa solução de continuidade do povo nas decisões do governo. É a forma de ouvi-lo e entendê-lo (audiência $=$ audire).

Se à sociedade foi, teoricamente, possível decidir a forma como será gasto o dinheiro que lhe pertence, não é razoável que as portas se fechem a ela para opinar quanto ao modo e os métodos de realização das políticas públicas; avaliar e monitorar a realização eficaz dessas ações governamentais, podendo alterar os seus rumos; controlar a execução orçamentária e ser informada acerca dos indicadores e metas fiscais.

$\mathrm{Na}$ legislação brasileira, a audiência pública atende a todas estas finalidades. Há inúmeros dispositivos que tratam acerca da sua realização. Na prática, porém,

80 OLIVEIRA, Osmany Porto de. Abraçando a participação local: a construção da democracia na África a partir dos territórios. Disponível em: <http://osmanyporto.wixsite.com/difusaodepoliticas/artigos>. Acesso em: 16 jan. 2017. 
a pouca importância que o instituto recebe nos faz mais espectadores do que sujeitos do nosso próprio destino.

A Constituição Federal de 1988 determina que a administração pública haja com eficiência (art. 37). Ter eficiência, no entanto, não diz respeito somente à conformação dos atos administrativos à lei, tampouco representa apenas a observância da relação aritmética de custo e benefício, mas significa, também, atentar para todas as possibilidades de obter a melhor decisão, o melhor contrato, e que ele não seja submetido à escolha discricionária do gestor, facilitando a ocorrência da corrupção. É preciso que o poder público conte com a cooperação popular constante.

A audiência pública insere-se neste contexto como uma ferramenta de participação cívica aberta à sociedade, que possibilidade a intervenção direta dos cidadãos na gestão dos órgãos e entidades públicas, por meio do qual se exerce o direito de expor pontos de vista, críticas, preferências e avaliações, de modo a influenciar nos rumos das decisões e políticas governamentais.

É a via pela qual transita o direito fundamental de ser ouvido como membro da comunidade e se adquire estatura de cidadão ativo. Por isso, qualifica-se, a um só tempo, como: a) vetor de transparência, tendo em vista que pressupóe informar os participantes a respeito do objeto tratado; b) legitimador de decisões políticas, já que, ao inseri-lo, torna o cidadão parte das ações governamentais das quais ele próprio é o destinatário; c) arenas de veto, uma vez que tem a capacidade de alterar e formar políticas públicas e; d) instrumento de controle social, porquanto permite acompanhar e fiscalizar a execução orçamentária e a efetividade dos programas sociais.

Tais características bastariam para afirmar que, mesmo nos casos em que a legislação não imponha expressamente a sua realização, a audiência pública deve necessariamente preceder as escolas mais sensíveis do poder público.

No entanto, ainda que a LRF estabeleça uma audiência pública para avaliação do cumprimento das metas fiscais de cada quadrimestre em todas as esferas de governo (art. $9^{\circ}, \$ 4^{\circ}$ ); que o Decreto n. 8.243/2014 obrigue a administração pública federal direta e indireta a considerar os mecanismos de participação na formulação, execução, monitoramento e avaliação de suas políticas públicas (art. 5o); ou que a Lei n. 10.527/2001 preveja o dever de utilização das audiências públicas na gestão das cidades (art. 43, I);81 a eficácia desses dispositivos ainda é muito baixa no Brasil.

81 Outros dispositivos legais ou infralegais que contemplam a realização de audiências públicas: art. 58, \$ 2º, II, da Constituição Federal de 1988; art. 39, da Lei n. 8.666/93 (Lei de Licitaçôes e Contratos Administrativos); art. 32 a 35, da Lei n. 9.784/99 (Lei do Processo Administrativo Federal); art. $9^{\circ}, \$ 1^{\circ}$, da Lei n. 9.868/99; art. $3^{\circ}$ e $7^{\circ}$, I e II, da Lei n. 8.987/95; art. $1^{\text {o }}$, VIII, $5^{\circ}$ e 16, do Decreto n. 8.243/2014. 
As dificuldades que atravessam a realização da audiência pública, enfraquecendo a sua qualidade no país, são em certa medida semelhantes àquelas que foram atribuídas ao orçamento participativo. Poder-se-ia apontar: a) o vácuo de comunicação criado pela insuficiência dos métodos de publicidade das audiências públicas, tanto em relação aos avisos prévios destinados a convocar o maior número de participantes, quanto às conclusões da administração sobre os trabalhos realizados na audiência; b) a comum imposição de percalços físicos à participação, como a escolha de locais remotos ou horários inconvenientes; c) a utilização de procedimentos que inviabilizam a exposição adequada de ideias, negando aos participantes a possibilidade de se manifestar, ou responder, a fim de estabelecer um diálogo (e não um monólogo) que demonstre se determinada técnica é boa ou não, ou se há alternativas melhores em termos de eficiência; d) enfraquecimento das reivindicações por parte da sociedade civil, onde a população não tem pressionado as autoridades públicas para realização das audiências públicas; ${ }^{82}$ e) a não vinculação da administração ao que fora deliberado na audiência pública. Na maioria dos casos, é a própria lei que a caracteriza como mera consulta pública, despida de caráter vinculante em relação à escolha final do gestor ${ }^{83}$ Ao menos deveria recair sobre a autoridade o ônus de explicar, caso assim procedesse, o porquê da não consideração dos debates públicos. É frustrante para quem participa, perceber que as conclusões alcançadas coletivamente, após uma série de discussões, foram simplesmente ignoradas ou distorcidas. ${ }^{84}$ Não raro são decisões que já estão tomadas de antemão, mas que o agente político faz passar pelo crivo de uma audiência pública meramente formal, a fim de apresentar a sua escolha, sem possibilidades de alteração posterior. Comportamentos como este apenas aprofundam a percepção do cidadão de que sua opinião tem pouco valor na arena pública e que, portanto, é desinteressante participar. A propósito, não podemos ignorar o fato de que a má-gestão e os desvios públicos encontram no desinteresse da sociedade um campo fértil para proliferar.

Referidos mecanismos de democracia direta, além de outros que se encarreguem de elevar o cidadão à condição de coautor do planejamento estatal, reclama

82 Cabe lembrar que, quando há um requerimento dos cidadãos para promoção da audiência, e o poder público se nega a pô-la em prática, o ato administrativo que for objeto desse pedido será nulo.

83 Decreto n. 8.243/2014. Art. 10 Parágrafo único: (...) VIII - Audiência Pública: mecanismo participativo de caráter presencial, consultivo, aberto a qualquer interessado, com a possibilidade de manifestação oral dos participantes, cujo objetivo é subsidiar as decisóes governamentais.

84 BOBBIO, Luigi. Dilemmi dela democrazia participativa. Democrazia e Diritto, Roma, 2006, fasc. 4, p. 22. No original: "La loro forza deve risiedere nell' influenza che riescono a esercitare, non nei poteri legali che sono loro attribuiti” (tradução livre). 
por maior valorização no Brasil, eis que são constantemente substituídos por procedimentos cujo nome é semelhante, mas o conteúdo completamente diverso, destinados a tornar a capa mais apresentável do que as páginas.

O povo é o único sensor de seu governo, como outrora afirmou Thomas Jefferson. Caso ele, o povo, deixe de exercer o controle social daquilo que, no final das contas, lhe pertence, está dando a democracia como garantia para a prática de corrupção. Tudo depende da nossa participação. Depende de cada um de nós aceitar a responsabilidade da cidadania, independentemente do rumo seguido pelo pêndulo do poder.

\section{Terceiro eixo: impunidade - indutora de corrupção}

Norberto Bobbio, conhecido pela extensa lista de obras importantes sobre política e democracia na Itália e no mundo, considera imprescindível fazer três perguntas caso pretenda-se perquirir o nível de efetividade de um regime democrático. A primeira: a classe política deriva o seu poder diretamente do consenso popular? Se sim, é legítima; se não, é ilegítima e, portanto, antidemocrática. A segunda: qual a intensidade e rapidez da circulação da classe política? Se altas, é móvel; mas se baixas, é imóvel e, deste modo, autoritária. A última: Está plenamente em ação o princípio da responsabilidade dos que detém o poder de governar? Se sim, é porque há um sistema de accountability eficaz; se não, é porque prospera nessa sociedade a impunidade..$^{85}$

Acaso um extraterrestre pousasse de repente em território tupiniquim e fosse compelido, após alguns dias de observação e análise, a responder essas três questôes, talvez tivesse dificuldades em resolver as duas primeiras, apresentando respostas genéricas e imprecisas, mas certamente não titubearia em dizer que "não" quanto à última indagação. Infelizmente, o alienígena levaria à Marte a impressão de que somos uma sociedade ainda marcada pela indulgência aos infratores.

Porém, antes que a sua nave decolasse, preocupados com a nossa reputação, poderíamos explicar que não é sem razão que o sistema funciona da maneira como vem se desenvolvendo, e que talvez não seja nossa culpa.

Salta aos olhos o fato de que o Brasil é um país, historicamente, desigual. Não faltam pesquisas e índices que nos colocam no topo dos rankings de iniquidade social, educacional e de renda. Ao se perguntar o motivo pelo qual os brasileiros se diferenciam tanto nesses aspectos, provavelmente a resposta seria um amargurado e pesaroso: sempre foi assim!

85 BOBBIO, Norberto. Entre duas Repúblicas: as origens da democracia italiana. Brasília: UnB, 2001. 
Talvez não sempre, mas durante um longo período - pelo menos por cinco séculos - sustentávamos e ainda sustentamos o lastimável peso do patrimonialismo, do clientelismo e da patronagem, característicos da colonização ibérica, onde facilmente se confundia o público com o privado. Parafraseando Nelson Rodrigues: patrimonialismo não se improvisa; é uma obra de séculos.

O poder estamental fortemente concentrado e o patrimonialismo forneceram as bases para a formação de uma sociedade de privilégios, onde os membros privilegiados pensam e agem conscientes de pertencer a um mesmo e restrito grupo, a um círculo elevado, qualificado pelo exercício do poder. Das capitanias aos cargos políticos; da fidalguia ao foro privilegiado. Não é de surpreender que ainda em 1883, antes mesmo da proclamação da República Federativa dos Estados Unidos do Brasil (1891), o sergipano Tobias Barreto já discursava da seguinte forma:

É certo que, a despeito de todas as aparências e exteriores constitucionais, a sociedade brasileira em sua generalidade é uma sociedade de privilégios, senão criados por lei, criados pelos costumes (...) a penúria moral em que vivemos, o desanimo dos espíritos, o abandono de si mesmo, o esquecimento de seus direitos, pelo patrimonialismo, pela falta de justiça, dignidade política e liberdade, de que todos nós sentimo-nos sequiosos. ${ }^{86}$

Esse estado patrimonial, já adiantava Raymundo Faoro, “implacável nos seus passos, não respeitará o peso dos séculos" ${ }^{87} \mathrm{E}$ não respeitou. Como na mais forte resina, conversou-se firmemente no tempo e ainda hoje ressoa em território brasileiro. Jornalistas e jornaleiros sabem que essa reminiscência aristocrática se manifesta de diversas formas: a partir da troca de favores e cargos públicos (patronagem); da apropriação de bens e recursos públicos em prejuízo da sociedade (rent-seeking); dos privilégios injustificados a pequenos grupos (capitalismo de compadrio) e, principalmente, da impunidade.

É desnecessário dizer a influência que isso exerce sobre os níveis de corrupção do país, na medida em que alimenta um círculo vicioso que é péssimo para a democracia: quanto mais o agente percebe ou possui certeza de que não haverá resposta imediata à prática dos ilícitos que cometeu, mais incentivos haverá para a sua reincidência e para a inserção de outras pessoas neste mesmo ciclo perverso. Em tal cenário, a corrupção é produto da soma positiva entre o alto proveito e o risco de punição improvável. Do tempo que essa roda gira no Brasil, é possível dizer que há uma cultura de impunidade, segundo a qual é fácil desobedecer às leis nacionais e,

86 BARRETO, Tobias. Obras completas. IV, Discursos. Edição do Estado de Sergipe, 1926, p. 123.

87 FAORO, Raymundo. Os donos do poder: formação do patronato político brasileiro. 3. ed. rev. Rio de Janeiro: Globo, 2001. 
sempre que possível, deve-se optar pelo uso do jeitinho brasileiro ao invés de submeter-se às regras do jogo. ${ }^{88}$

Quando falamos da necessidade de tornar os agentes públicos responsáveis, ou seja, que respondam pelas suas condutas independentemente do poderio de que dispõem, obviamente não é desejável que sejam atirados de helicópteros em pleno voo, como ameaçou fazer com os corruptos de seu país o presidente das Filipinas, Rodrigo Duterte; ou que recebam um número específico de chibatadas, tal como aconteceu com o ex-Procurador Geral do Teerã, Saeed Mortavazi, pela condenação por desvio e desperdício de dinheiro público. Para a sociedade, é bastante que haja sequer a punição, dentro do devido processo legal, ainda que não seja tão extremada.

Com efeito, o conceito de impunidade não pode ser associado exclusivamente à ausência de castigo ou punição, mas possui relação estreita e definitiva também com o estado de direito - ou a sua deficiência, e com a efetividade dos órgãos de controle.

Em virtude da necessidade de delimitar os temas aqui tratados, uma vez que minha pretensão não é cansá-los, e por questões de domínio técnico, nos ocuparemos aqui do último caso: a efetividade dos organismos de fiscalização e, particularmente, dos tribunais de contas brasileiros.

Portanto, é importante deixar consignado desde já que não trataremos de assuntos que, costumeiramente, veem à cabeça quando o assunto é impunidade. Não que sejam destituídos de relevância prática, pelo contrário. Deste modo, o foro por prerrogativa de função, mais conhecido como foro privilegiado ou, como ouvi recentemente: desaforo dos privilegiados; o alto índice de prescrição dos crimes de colarinho-branco, expressão cunhada por Edwin Sutherland como referência aos delitos econômicos praticados pela elite social; a execução da pena privativa de liberdade após a condenação em segunda instância, serão tratados em outra oportunidade, talvez em outro livro.

Nesta obra, nos concentraremos, conforme já foi dito, na efetividade das decisões condenatórias dos Tribunais de Contas brasileiros e as implicações disso no cumprimento da Lei da Ficha Limpa. Muito específico? Talvez. Pode até parecer que não mereça muito a nossa atenção, mas não se engane. Por isso, não pule o capítulo. Saiba primeiro que muito dinheiro é escoado na via pela qual transita a

88 "A maioria dos entrevistados respondeu que concorda com a afirmação de que 'é fácil desobedecer às leis no Brasil' (82\%). Em segundo lugar, nota-se que 79\% dos entrevistados concordam com a afirmação de que o cidadão brasileiro, sempre que possível, opta pelo "jeitinho" ao invés de obedecer à lei”. Fundação Getúlio Vargas. Direito GV. Relatório IPCL Brasil, 4a Trimestre/2012-1\%, p. 14. 
dificuldade das Cortes de Contas em executar as suas próprias decisões. São condenaçôes que simplesmente se perdem, tornadas tão frágeis como castelos de areia. O caminho que as separa da efetividade tem se alongado cada vez mais.

Embora seja irremediavelmente otimista, os fatos e julgamentos que sucederam nos últimos anos e que afetaram diretamente os tribunais de contas não me permitem passar uma visão tão esperançosa e progressista como desejava.

Apesar disso, não tenho a intenção de compartilhar desalento ou desesperança com o leitor. Antes, quero colocá-lo a par dessa situação que é tão séria quanto inquietante, pois aflige parcela considerável de dinheiro público. Para isso, será necessário abandonar um pouco da complexidade que o próprio tema exige.

Comecemos por ordenar as ideias: primeiro, falaremos acerca dos tribunais de contas; de que modo eles foram acolhidos no texto da Constituição, se como órgão autônomo ou subordinado e quais as competências que ela lhes outorgou; segundo, teremos de abordar a maneira como esses órgãos de controle externo examinam as contas públicas e quando ele decidirá ou não sobre elas e como essas decisões serão executadas posteriormente; terceiro e último, examinaremos porque essas execuções não surtem os efeitos almejados e, por conseguinte, deixamos de recuperar uma boa quantia de recursos malversados.

\section{A Constituição Federal e o Tribunal de Contas}

A história já se cansou de dar mostras de que o poder é semelhante ao colesterol: quanto mais se tem, tanto mais perigoso se torna. Filósofos revolucionários como Montesquieu e Montaigne absorveram cedo essa valorosa lição. $\mathrm{O}$ primeiro chegou a dizer que todo o poder tende a corromper-se e todos os que o possuem são levados mais cedo ou mais tarde a abusar de seu emprego. Só havia um remédio capaz de estancar essa propensão natural ao arbítrio: o controle.

Foi com isso em mente que, ao fornecer as bases teóricas para a elaboração da pioneira Constituição norte-americana de 1787, James Madison afirmou que se os homens fossem governados por anjos, o governo não precisaria de controles externos nem internos. ${ }^{89}$ Como não são os anjos, mas os homens que exercem a arte de governar, os organismos de fiscalização se fazem imprescindíveis.

Apenas dois anos mais tarde, quando estourara a segunda Revolução Liberal que marcou o século XVIII, os franceses trataram de consignar expressamente na Declaração dos Direitos do Homem e do Cidadão, de 26 de agosto de 1789, que "a

89 MADISON, James. The Federalist No 51, the Federalist. New York: Modern Library, p. 337. 
sociedade tem o direito de pedir contas a todo o agente público pela sua administração", dando início à ideia de accountability e ao princípio da prestação de contas.

A necessária existência de instituições de vigilância externa, além do dever dos agentes públicos de render contas à sociedade constituem, com efeito, os pais biológicos das instituiçôes superiores de controle (ISC), dentre elas os tribunais de contas, que começaram a ser reivindicados logo após estes acontecimentos. Napoleão I, por exemplo, cobrava a fiscalização ativa dos fundos públicos através de uma corte especializada. ${ }^{90}$

No Brasil, não obstante cogitações e projetos malsucedidos de criação do órgão responsável pelo exame dos cofres públicos durante o período imperial, foi o Decreto n. 966-A, de 7 de novembro de 1890, assinado por Marechal Deodoro da Fonseca e Ruy Barbosa, então Ministro das Finanças, que providenciou a criação do Tribunal de Contas no modelo que conhecemos hoje, para o exame, revisão e julgamento dos actos (sic) concernentes à receita e despeza (sic) da República. ${ }^{91}$

Desde então, a corte de contas acompanhou a história da República Brasileira, marcando presença dos textos constitucionais que sucederam até a Carta de 1988.

$\mathrm{Na}$ Lei Maior promulgada em 05 de outubro de 1988, a instituição recebeu tratamento especial, uma vez que teve suas atribuições consideravelmente ampliadas pelo art. 71, bem como elevou a prestação de contas ${ }^{92}$ dos agentes públicos à condição de princípio constitucional fundamental à noção republicana, previsto no art. 34, VII, alínea "d", da Carta.

Para além disso, é irrecusável que deu aos órgãos de controle autonomia no desempenho destas funções, embora alguns ainda persistam em não reconhecer tal condição. Isso porque o texto constitucional, ao seguir o modelo estabelecido na Itália - que posiciona o tribunal de contas na sessão III, dos "órgãos auxiliares" consignou no art. 71 que a titularidade do controle externo pertence ao Poder Legislativo, que o exerce com o auxílio das cortes de contas. Sucede que o uso do termo "auxílio", pela CRFB/88, fez surgir a ideia equivocada de que tratar-se-iam

90 ROSANVALLON, Pierre. El buen gobierno. Buenos Aires: Manantial, 2015, p. 201.

91 BRASIL. Senado Federal. Decreto n. 966-A, de 07 de novembro de 1890. Disponível em: <http://www2.camara.leg.br/legin/fed/decret/1824-1899/decreto-966-a-7-novembro-1890-553450-publicacaooriginal-71409-pe.html>. Acesso em: 20 jan. 2017.

92 A prestação de contas é a operação a que está obrigada a realizar toda a pessoa que tenha encomendada a administração de bens alheios, pela qual expõe o estado do patrimônio administrado e as gestôes realizadas para a sua conversão, com indicação de tudo quanto há realizado no desempenho de sua missão, de tudo o que foi gasto e recebido, além de todas as obrigações que assumiu perante terceiros. 
de órgãos subordinados ao parlamento, e que seria impossível conceber uma instituição autônoma dentro do sistema de separação de poderes.

A mesma celeuma ocorre no âmbito do Tribunal de Contas da Espanha. Na Constituição Federal espanhola de 1978, o art. 136 estabelece que o Tribunal de Cuentas é um órgão supremo de fiscalização, contudo, com dependência em relação às Cortes Gerais, entidade do Poder Legislativo. Sobre este termo (dependência) utilizado pela Carta Magna, Manuel Núñes Pérez, ex-presidente do Tribunal de Contas Federal da Espanha, afirma não significar que a corte de contas seja um órgão do parlamento, senão que realiza o controle como atividade instrumental ou de apoio do mesmo, resguardando, no entanto, a independência funcional como órgão técnico que contribui à fiscalização política empreendida pela Casa Legislativa. ${ }^{93}$

Nem uma coisa, nem outra. Embora não faça parte do programa expositivo que estamos seguindo para mostrar a vocês, interlocutores, as razões da crise brasileira, permitam-me abrir um parêntesis para explicar rapidamente porque os tribunais de contas são independentes e soberanos na função de fiscalizar, do ponto de vista estrutural, funcional e lógico.

Primeiro, apesar de o Tribunal de Contas figurar no Título IV (Organização dos Poderes) da Carta da República, precisamente no Capítulo I, referente ao Poder Legislativo, o art. 44 não deixa dúvidas que este último é composto tão somente pelo Senado Federal e pela Câmara dos Deputados. Não há menção alguma às Cortes de Contas neste dispositivo. Estruturalmente, portanto, os tribunais de contas não integram o parlamento. Seria até mais coerente que estivesse no Capítulo IV, atinente às Funções Essenciais da Justiça, junto ao Ministério Público, advocacia pública e privada e a Defensoria Pública.

Segundo, das funções que a Constituição outorgou ao tribunal de contas no art. 71, somente quatro delas estão condicionadas à análise ou aval do Poder Legislativo: apreciação das contas do chefe do Poder Executivo e emissão do parecer prévio (inc. I); prestar informações solicitadas pelo parlamento sobre a fiscalização (inc. VII); sustação de atos impugnados, com a comunicação subsequente ao Senado e a Câmara dos Deputados (inc. X) e; representar o poder competente sobre irregularidades (inc. XI). As demais - e constituem maioria (sete) - são exercidas de forma exclusiva pelo tribunal de contas, sem interferências: julgamento das contas dos administradores e demais responsáveis por dinheiros públicos, melhor dizendo, a jurisdição contábil (inc. II); apreciar a legalidade de atos de admissão de

93 PÉREZ, Manuel Núñes. De la Constituición Española al Tratado de Lisboa: trienta años del Tribunal de Cuentas. Revista Española de Control Externo, v. XI, n. 31, 2011, p. 23. 
pessoal e aposentadorias (inc. III); iniciar inspeções e auditorias de natureza financeira, operacional e contábil (inc. IV); fiscalizar as contas nacionais das empresas supranacionais (inc. V); fiscalizar a aplicação de recursos repassados pela União mediante convênio (inc. VI); aplicar aos responsáveis, em caso de ilegalidade, sanções (inc. VIII); assinalar prazo para que órgão ou entidade adote as providências necessárias ao exato cumprimento da lei (inc. IX). Portanto, tampouco é funcionalmente subordinado.

Terceiro, na sua missão fiscalizatória, cabe ao tribunal de contas controlar orçamentária e financeiramente o próprio Legislativo, vez que o art. 71, IV, permite-o realizar fiscalização por iniciativa própria nas unidades administrativas do parlamento. Onde há subordinação, não poderia existir controle pelo órgão subordinado, com a possibilidade, inclusive, de imposição de punições. Logicamente, também não existe essa dependência.

Não se trata, portanto, de um auxílio da corte de contas a ponto de convertê-la em órgão de assessoramento, mas de ressaltar a sua essencialidade para o Poder Legislativo, destinatário imediato dos resultados obtidos no exercício das competências de controle que aquele órgão de contas exerce.

Fecho os parêntesis.

Para ingressarmos de vez ao exame da inefetividade de suas decisões, toca analisar mais de perto as duas principais competências dos tribunais de contas presentes no art. 71, que são as de apreciar contas de governo e julgar contas dos administradores e responsáveis por dinheiros públicos, os denominados ordenadores de despesas.

No primeiro caso, das contas de governo, também denominadas contas de desempenho ou de resultados, objetivam demonstrar o cumprimento do orçamento, dos planos e programas de governo (PPA, LDO e LOA). Referem-se, portanto, à atuação do chefe do Executivo enquanto mandatário político. A Constituição reserva à Casa Legislativa correspondente a competência para julgá-las em definitivo, mediante parecer prévio do Tribunal de Contas.

Já as contas de gestão, chamadas também de contas de ordenação de despesas, possibilitam o exame, não dos gastos globais, mas de cada ato administrativo que compõe a gestão contábil, financeira, orçamentária, operacional e patrimonial do ente público, quanto à legalidade, legitimidade e economicidade. A competência para julgá-las é do Tribunal de Contas, em definitivo - portanto, sem a participação do parlamento.

A Constituição de 1988 reconhece, portanto, ao tribunal, uma dualidade de competências em relação às contas públicas, o que fica claro quando se verifica que 
ela se vale de verbos diferentes para iniciar cada inciso. No primeiro, emprega o termo "apreciar" (...) mediante parecer prévio; no segundo: "julgar" as contas (...). Haveria, portanto, uma divisão das figuras do chefe político e do ordenador de despesas, com regimes de responsabilidade, causas e consequências diferentes. $\mathrm{O}$ primeiro, necessariamente chefe do Poder Executivo, se encarrega da gestão política. Já o segundo, não necessariamente mandatário do Executivo, mas podendo também o ser, como ocorre nos pequenos municípios, onde os prefeitos acumulam as duas figuras.

\section{Inefetividade: o problema por detrás da impunidade}

Compreendidas essas questões preliminares, cabe-nos fazer a constatação de uma triste realidade que já é notória: as decisões dos Tribunais de Contas, quer sejam os pareceres prévios ou os julgamentos, não apresentam a efetividade que a sociedade espera, tampouco a força que a própria Constituição Federal pretendeu lhes conferir. Prova dessa deficiência é o índice baixíssimo de recuperação ou recolhimento dos valores aplicados a título de multa pecuniária e ressarcimento ao erário por estas cortes, que não passa de $20 \%,{ }^{94}$ bem como a taxa paupérrima de pareceres prévios analisados pelo Poder Legislativo e que geram consequências sérias aos maus-gestores.

Essa é uma ingloriosa realidade com a qual têm de lidar não somente aqueles que trabalham no controle externo, como eu, como também o cidadão, como você, pois é do seu dinheiro de que estamos falando.

Neste aspecto, há a sensação de que estamos morrendo na praia, e que qualquer lampejo de efetividade, se possível, seria como uma flor nascida no asfalto, de tão extraordinário. Não há como deparar-se com tal situação e não se perguntar os motivos pelos quais as decisões da corte de contas têm de enfrentar tamanhas dificuldades

94 Essa média foi alcançada mediante uma pesquisa realizada através dos Relatórios de Atividades dos Tribunais de Contas estaduais. A escassez e/ou insuficiência dos dados disponibilizados pelas Cortes estaduais não permitiu lograr uma média cientificamente objetiva acerca do índice de recuperação dos valores de multas e débitos aplicados. Com efeito, poucos tribunais de contas oferecem essa informação de forma adequada (ex.: TCE-PR, TCE-TO, TCE-MG, TCE-BA; TCE-RO; TCE-RJ), ainda assim, os números não são perfeitamente críveis, uma vez que não é possível especificar se os valores colocados como "recuperados" dizem respeito a débitos/multas de exercícios anteriores ou do ano corrente. Outros tantos tribunais sequer viabilizam esses dados (ex.: TCE-SC, TCE-SP, TCE-RN, TCE-AC, TCE-PI, TCE-AP), impossibilitando a composição de um percentual completo. Há ainda aqueles cujas informaçôes, não obstante a disponibilização, são incompletas, dando somente o valor das condenações (TCE-RS, TC-DF, TCE-MA), ou apenas o valor recolhido (ex.: TCE-ES). 
de efetivação. Lhes mostrarei. Para tanto, contudo, devemos ver separadamente os dois lados da moeda do art. 71 da Constituição.

O leitor poderá verificar, ao final, que essas dificuldades que fazem encolher tanto a credibilidade dos órgãos de controle externo, são, na verdade, alheias à sua vontade, consequência da inapetência de outros órgãos ou entidades.

\section{Das Contas de Governo (art. 71, I, CRFB/88)}

Com relação às denominadas contas de governo, que são aquelas sobre as quais o tribunal de contas apenas emite um parecer prévio, o problema se concentra no descompromisso do Poder Legislativo em julgá-las definitivamente.

A Constituição Federal fixa, no art. 51, II, o prazo de sessenta dias para que o chefe do Poder Executivo encaminhe a sua prestação de contas ao Congresso Nacional. $\mathrm{O}$ art. 71, I, por sua vez, diz que o parecer prévio da corte de contas deverá ser elaborado no mesmo prazo de sessenta dias. Apenas a decisão do parlamento sobre as contas permanece destituída de qualquer restrição temporal.

Assim, o Tribunal de Contas mobiliza a sua equipe técnica, faz uma análise complexa sobre o ano fiscal do Presidente, governador e prefeito, emite o respectivo parecer prévio, opinando pela regularidade, irregularidade ou regularidade com ressalvas das contas, envia ao Parlamento, que simplesmente não julga, e quando julga, em inúmeros casos ignora a conclusão técnica do parecer, sem, contudo, apresentar motivações consistentes. Inviabiliza, com isto, que a sociedade conheça os resultados da prestação de contas, coisa que lhe diz respeito, diretamente.

Ao agir dessa forma, o Poder Legislativo deixa um buraco aberto no ciclo orçamentário, que remanesce incompleto. Um campo santo de irresponsabilidade política. Pouco adianta o poder ao qual cabe representar a vontade popular aprovar o orçamento, porém se omitir na decisão sobre a regularidade ou não da execução pelo administrador público. Além disso, acaba por inutilizar o trabalho técnico das cortes de contas, bem como livra o gestor público irresponsável das consequências legais da má-gestão.

Prova concreta desse descompromisso foi o julgamento conjunto, em 2015, à toque de caixa, de várias contas presidenciais que se encontravam estocadas na Câmara Federal desde a gestão presidencial de Itamar Franco (1992-1995), que só foram julgadas, diga-se de passagem, em virtude do ímpeto voraz do então Presidente da Câmara em alcançar as contas da ex-presidente Dilma Rousseff. As próprias contas anuais da ex-presidente se tornaram um enigma. Após a emissão do parecer prévio sobre o exercício de 2014, pelo TCU, em 07 de outubro de 2015, repercutindo massivamente nos noticiários em virtude da exposição das pedaladas fiscais com a Caixa 
Econômica Federal, Banco do Brasil e BNDES, e do impulso que deu à iniciação do processo de impeachment, a população acompanhou de perto o trâmite do parecer na Comissão Mista Permanente de Planos, Orçamentos Públicos e Fiscalização (CMPOF), a quem cabe elaborar parecer conclusivo antes do julgamento definitivo das contas no Plenário do Congresso. Pouco tempo depois, em vista da sucessão de escândalos no âmbito da Operação Lava-Jato, não se ouvia mais comentários sobre as contas no Poder Legislativo, e lá elas permaneceram. Agora esquecidas, já completam três aniversários, se juntando aos demais pareceres prévios de gaveta que guarnecem o parlamento brasileiro. O mesmo sucedeu com as contas presidenciais de 2015, que não tiveram semelhante repercussão, embora tenha-se apontado maior número de irregularidades. O seu paradeiro também é desconhecido.

Esse cenário de não julgamento se repete, ainda, nas assembleias legislativas e nas câmaras municipais.

É na ausência de consequências jurídicas que os parlamentos encontram estímulo para perpetuar essa omissão. $\mathrm{O}$ caráter eminentemente político da decisão serve como pretexto para que a negligência dos legisladores não surta quaisquer efeitos, quer sancionatórios, quer em relação ao parecer prévio, haja vista o veredito do Supremo Tribunal Federal, tomado em repercussão geral, no sentido de que cabe exclusivamente à câmara de vereadores o julgamento das contas anuais do chefe do Poder Executivo local, não cabendo o julgamento ficto por decurso do prazo. ${ }^{95}$ Isto é, mesmo que a Casa Legislativa se recuse a promover o julgamento, o parecer prévio do Tribunal de Contas não terá eficácia, ainda que o art. $31, \mathbb{2}$, da CRFB/88 diga que "o parecer prévio (...) só deixará de prevalecer por decisão de dois terços dos membros da Câmara Municipal”. Em outras palavras: impunidade por decurso do prazo.

Estabelecer consequências é importante para inibir determinadas condutas, e os tribunais precisam sanar essa omissão através da jurisprudência, enquadrando a renitência do Poder Legislativo, quando constatar que decorra de arranjos ilícitos ou influência perniciosa do gestor, como prevaricação (art. 319, do CP) ou corrupção passiva privilegiada (art. $317, \S 2^{\circ}$, do $\mathrm{CP}$ ).

\section{Das Contas de Gestão (art. 71, II, CRFB/88)}

Há outros problemas que permeiam as contas de gestão, aquelas em que o tribunal de contas não se basta na emissão de um parecer opinativo, realizando ele próprio o julgamento definitivo das contas.

95 STF, RE n. 729.744. Rel. Min. Gilmar Mendes, DJE de 17.08.2016. 
Se, ao realizar esse julgamento, o tribunal verificar a ocorrência de alguma ilegalidade, além de determinar a irregularidade das contas, deverá aplicar sanções patrimoniais ao gestor público, que poderão consistir no ressarcimento ao erário e multa. ${ }^{96} \mathrm{O}$ que distingue os dois casos é a natureza da punição. A multa consiste em medida de caráter punitivo, enquanto o ressarcimento tem feição civil, já que implica na recuperação de recursos que foram subtraídos dos cofres públicos por atos ilícitos, com base nos arts. 186 e 927, do Código Civil. ${ }^{97}$

Pois bem. Diz o art. 71, $\$ 3^{\circ}$, da CRFB/88, que essas decisões que impõem condenação patrimonial aos responsáveis por irregularidades no uso de bens e valores públicos têm eficácia de título executivo, e que essa regra se aplica tanto em âmbito federal, quanto estadual e municipal (art. 75, da CRFB/88).

Isso significa que os ressarcimentos e as multas aplicadas pelo Tribunais de Contas estão sujeitos à cobrança pelo meio executivo. E é justamente aqui que se concentram os pontos de inefetividade do julgamento das contas.

A Constituição Federal deixou em aberto duas questôes essenciais: a legitimidade para promover a execução e a natureza desses títulos executivos. Tais questôes têm influência imediata na efetividade das decisões e que podem ser mais facilmente formuladas da seguinte forma: quem executa? Executa o quê? Analisemos cada uma dessas interrogações.

\section{Quem executa?}

A Constituição não diz. No seu silêncio, coube ao Supremo Tribunal Federal, que tem a missão de interpretá-la, anunciar quem seria o legitimado para levar esse título executivo ao Poder Judiciário e pedir a respectiva execução. A Corte Suprema decidiu, por conseguinte, com repercussão geral para todos os outros casos semelhantes, que não é o tribunal de contas o órgão titular da legitimidade para promover a execução de suas próprias decisões, seja diretamente ou por meio do Ministério Público que atua perante ele. ${ }^{98}$ Tampouco poderia o Ministério Público comum ajuizar essas execuções como legitimado extraordinário, ou seja, atuando em nome próprio na defesa de direito alheio (da sociedade), com base no art. 129, III, da CRFB/88, que coloca como função institucional deste órgão a proteção do patrimônio público. ${ }^{99}$

96 Conforme o art. 71, VIII, da CRFB/88.

97 Art. 186. Aquele que, por ação ou omissão voluntária, negligência ou imprudência, violar direito ou causar dano a outrem, ainda que exclusivamente moral, comete ato ilícito; art. 927. Aquele que, por ato ilícito (arts. 186 e 187), causar dano a outrem, fica obrigado a repará-lo.

98 STF, RE n. 223.037. Rel. Min. Maurício Corrêa, j. 02.05.2002.

99 Essa posição restou estabelecida tanto no STF, conforme se nota do RE n. 791.575/MA, Rel. Min. Marco Aurélio, j. 29.04.2014, como no STJ, que também analisou o tema. 
Deste modo, o entendimento consolidado foi que a ação de cobrança - ação de execução de título executivo - somente pode ser proposta pelo ente público beneficiário da condenação, através de seus procuradores. ${ }^{100}$ Melhor dizendo: somente o ente da Administração Pública prejudicado pelo ato irregular do gestor condenado tem legitimidade para propor no Judiciário, através da advocacia pública, a execução dos Acórdãos sancionatórios dos tribunais de contas.

$\mathrm{Na}$ prática, portanto, tem-se que as condenações impostas pelo TCU devem ser executadas pela União Federal, por intermédio da Advocacia-Geral da União (AGU). Já as sanções imputadas pelos Tribunais de Contas estaduais e municipais são efetivadas pela Procuradoria do Estado, na hipótese de ser um estado o ente prejudicado, ou pela Procuradoria do Município, caso seja este o lesado.

É desnecessária explicação mais aprofundada ou uma imaginação muito fértil para perceber que essa sistemática é desfavorável ao tribunal de contas e suas decisões, a considerar a influência que esses órgãos de representação judicial podem sofrer da esfera política. Talvez no âmbito federal essa realidade seja menos evidente, já que a AGU é um órgão estruturalmente maior e com funções mais complexas, mas o mesmo não se pode afirmar em relação às esferas estaduais e, sobretudo, municipais. Não podemos esquecer que os municípios detêm suma importância no federalismo brasileiro, aos quais são destinadas quantias significativas de recursos públicos.

No plano local, em quase a totalidade dos casos, o chefe do Poder Executivo (prefeito) possui ingerência direta na atividade das procuradorias, podendo obstar qualquer pretensão quanto à execução de decisões condenatórias contra ele.

Nesse cenário, ceder a legitimidade executória à procuradoria é o equivalente a entregar as chaves do galinheiro à raposa. Não há outro resultado senão a inefetividade. $\mathrm{O}$ quadro fica ainda pior quando se constata que nos municípios de pequeno porte, que constituem maioria no Brasil, sequer existe um órgão específico de representação judicial, com estrutura própria e servidores concursados. Diante disso, o prefeito usualmente terceiriza essa atribuição, contratando escritórios privados de advocacia para representar a prefeitura municipal na esfera judicial. $\mathrm{Na}$ maioria das vezes, contudo, essa contratação fundamenta-se no art. 25, II, da Lei

100 "Agravo regimental no recurso extraordinário. Administrativo. Tribunal de Contas do Estado. Imputação de multa a autoridade municipal. Execução de título executivo extrajudicial. Impossibilidade. Ausência de legitimidade. Precedentes" (STF, RE n. 525.663-AgR/AC, Rel. Min. Dias Toffoli). 
-• Finanças públicas: travessia entre o passado e o futuro

Geral de Licitações, ${ }^{101}$ ou seja, sem a realização da licitação pública. Acertos obscuros e fraudes não são incomuns nesse contexto.

Imagine-se, portanto, que o prefeito de um município de pequeno porte, que tenha contratado sem licitação um escritório de advocacia para a representação judicial do município, tenha sido condenado à devolução (ressarcimento) de determinada quantia, pelo tribunal de contas, em vista da constatação da ocorrência de desvios em recursos, por exemplo, da educação. $\mathrm{O}$ acórdão condenatório será enviado ao escritório advocatício para que este promova a execução do título gerado contra este gestor, no Poder Judiciário. Tomando-se em conta que o prefeito tem a prerrogativa de rescindir unilateralmente o contrato administrativo por razóes de interesse público (art. 78, XII, da Lei n. 8.666/93), é quase nula a probabilidade de que o escritório coloque em risco o seu ajuste com a prefeitura municipal a fim de compeli-lo ao cumprimento da decisão. A situação seria semelhante caso substituíssemos, neste exemplo, o prefeito por outro agente político aliado, ou que componha a sua base de sustentação política na Câmara dos Vereadores. É um labirinto sem saída.

O que executa?

A Carta da República também não disse, estabelecendo apenas que as decisões condenatórias do tribunal de contas constituem título executivo, sem, contudo, esclarecer a natureza desse título.

Assim como no caso anterior, ficou para o Supremo Tribunal Federal a tarefa de decidir a respeito, entendendo que, no Brasil, vige o princípio da unicidade ou monopólio da jurisdição, ou seja, somente ao Poder Judiciário cabe proferir decisóes que possam ser consideradas jurisdicionais. Portanto, o tribunal de contas, por não ser um órgão do judiciário, mas sim um tribunal administrativo, não emite provimentos jurisdicionais, e suas decisóes são títulos executivos de natureza extrajudicial (externos à jurisdição), assim como os demais títulos constantes do art. 784, do CPC/2015. Não pretendo abordar a controvérsia a respeito da natureza jurídica das decisões das cortes de contas, se judiciais ou não. Entendo que esse esclarecimento superficial é suficiente para avançarmos.

A diferença, a princípio supérflua, uma vez que as duas espécies de título podem ser satisfeitas igualmente, na verdade é substancial. Na execução dos títulos

101 Trata-se da inexigibilidade de licitação, a qual se dá nos casos em que a competição se mostra inviável, exigindo que a contratação seja realizada de forma direta. No caso do inciso II, do art. 25 , a lei permite a contratação direta para serviços técnicos, de natureza singular, com profissionais de notória especialização na área de atuação. 
judiciais, a defesa é feita por meio de impugnação, cujas matérias possíveis de serem alegadas pelo devedor são limitadas. Enquanto isso, na execução de títulos extrajudiciais, dentre os quais está o acórdão do tribunal de contas, o executado poderá oferecer embargos à execução, cujas matérias alegáveis em defesa incluem qualquer matéria que lhe seria lícito deduzir como defesa em processo de conhecimento. Com isso, o executado tem para si um campo amplíssimo de defesa, permitindo-lhe praticamente reabrir o processo no Poder Judiciário. Isso é afrontoso ao tribunal de contas de duas maneiras.

Primeiro: a corte de contas percorre um longo e sinuoso processo para proferir a decisão condenando o gestor, que geralmente prolonga-se durante anos. $\mathrm{O}$ órgão de contas mobiliza a sua equipe técnica, enviando-a para investigar a gestão por meio de auditorias in loco, faz um trabalho complexo de elaboração do relatório de auditoria, através de diferentes matrizes de planejamento. Por conseguinte, oportuniza-se ao responsável exercer o direito constitucional de defesa, contestando cada um dos apontamentos dos técnicos. O tribunal elabora e fundamenta o voto, leva-o ao colegiado para discutir e julgar a prestação de contas; possibilita-se ainda a apresentação de recursos, pedidos de reconsideração, reexame, revisão, embargos de declaração. Quando o veredito é levado à execução, para que surta os seus efeitos, todo esse percurso é desprezado pelo Poder Judiciário e a decisão da corte de contas converte-se no equivalente a um cheque ou nota promissória, assinadas e repassadas em menos de um minuto. Há, portanto, uma evidente falta de valorização, pelo Poder Judiciário, que se recusa na maioria das vezes em preservar as decisões administrativas dos tribunais de contas, o que dificulta muito a sua exequibilidade. ${ }^{102}$

Segundo: ao fazer isso, o Poder Judiciário também desrespeita a vedação ao denominado bis in idem, que proíbe a repetição de juízo sobre o mesmo fato. Além do mais, não há dúvidas de que, em matéria de contabilidade e finanças públicas, é o tribunal de contas o órgão mais especializado para fazer a avaliação.

\section{Não há nada tão ruim que não possa piorar}

Em "Cândido, ou O otimismo", Voltaire narra a história de um jovem que, após ser expulso do castelo onde habitava na região de Vestefália, influenciado pelas ideais de seu mestre, Dr. Pangloss, para quem todos os acontecimentos estão encadeados no melhor dos mundos possíveis, inicia uma jornada marcada por inúmeras desgraças: perde o seu amor; é torturado por búlgaros; sobrevive a um naufrágio

102 BILACHERIENE, Ana Carla. Controle da eficiência do gasto orçamentário. Belo Horizonte: Fórum, 2016, p. 209. 
para em seguida quase perecer em um terremoto; vê seu querido mestre ser enforcado em um auto de fé; é roubado e enganado sucessivas vezes. Durante esse penoso trajeto, Cândido tenta manter viva a filosofia de seu mestre, mas a cada nova catástrofe cresce a rejeição ao otimismo exagerado.

O caminho percorrido pelas decisões do Tribunal de Contas guarda muitas semelhanças ao drama vivenciado por Cândido. Evidentemente, não envolve torturas, enforcamentos ou terremotos, mas uma sequência de golpes que atingem em cheio a efetividade das condenaçôes. Ainda que fôssemos adeptos do otimismo-surreal pregado por Pangloss, certamente já estaríamos céticos quanto ao melhor dos mundos.

Como vimos, os valores referentes às sanções aplicadas pelo órgão de contas dificilmente são recuperados. Espero ter esclarecido os motivos pelos quais isso ocorre. Nesse contexto, o efeito mais contundente que as decisões que julgam irregulares as contas do gestor vinham surtindo era a suspensão de seus direitos políticos por intermédio da inelegibilidade, ou seja, a impossibilidade de concorrer às eleições por determinado período de tempo, com base no art. 10, I, "g", da Lei Complementar n. 64/90, alterada pela Lei Complementar n. 135/2010, popularmente gerada e conhecida como Lei da Ficha Limpa.

De acordo com esse dispositivo, quando o tribunal de contas, por decisão irrecorrível no âmbito do próprio tribunal, julga as contas irregulares de acordo com o art. 71, II, da CRFB/88, e constata a ocorrência de ato de má-fé caracterizado como improbidade administrativa (Lei n. 8.429/92), a Justiça Eleitoral poderia declarar a inelegibilidade do administrador condenado por oito anos. Não é exagero afirmar que, nesse aspecto, as decisões da corte de contas surtiam efeito expressivo, já que, de todas as inelegibilidades ocorridas nas eleiçôes municipais de 2012, $66 \%$ correspondiam a rejeição de contas pelo órgão de controle externo. ${ }^{103}$

Em agosto de 2016, contudo, a Corte Suprema entendeu que, em relação aos prefeitos que atuam como ordenadores de despesas, é dizer, que além de chefiarem a administração pública, realizam atos específicos de gestão como assinar empenhos, autorizar pagamentos, o que é raro na esfera federal e estadual, mas extremamente comum no âmbito dos municípios, não cabe a corte de contas julgar-lhes as contas, de modo que a palavra final seria do Poder Legislativo. ${ }^{104}$ Em suma, o

103 PASCOAL, Valdecir; RÉIS, Marlon. A ficha não pode cair. Associação dos Membros dos Tribunais de Contas do Brasil (ATRICON). Disponível em: <http://www.atricon.org.br/ artigos/a-ficha-que-nao-pode-cair/>. Acesso em: 25 jan. 2017.

$104 \mathrm{O}$ argumento que prevaleceu, originário do voto (vencedor) do ministro Ricardo Lewandowski, assenta que a competência para julgamento das contas será atribuída à Casa Legislativa 
Supremo Tribunal ignorou a diferença existente entre o inciso I e II, do art. 71, da Constituição Federal, em relação ao chefe do Poder Executivo, especialmente a atribuição de julgar as contas daqueles que realizem ordenação de gastos, bem como tornou letra morta a parte final do art. 1', I, "g", da LC n. 64/90, que é inequívoco ao dizer que: aplica-se o disposto no art. 71, II, da Constituição Federal, a todos os ordenadores de despesa, sem exclusão dos mandatários que houverem agido nessa condição.

Mandatários são os prefeitos e o que diz o inciso II é que o tribunal de contas "julga" as contas, o que de resto significa que o Supremo fechou os olhos para algo que está evidente na lei, limpando a ficha de mais de cinco mil prefeitos e ex-prefeitos no país, que tiveram suas contas de gestão rejeitadas pelas cortes de contas nos últimos anos.

Outras variáveis são gravíssimas: questões técnicas sobre atos concretos de ordenação do gestor, como o não pagamento de fornecedores para locupletar-se dos valores ou a não apresentação de notas fiscais, por exemplo, estarão sujeitas à absolvição política, que se dá sem qualquer fundamentação. E o contrassenso é ainda maior ao constatar-se que se retirou a possibilidade de atuação firme de um órgão independente, em detrimento de uma instituição que está naturalmente submetida a práticas de clientelismo e chantagem política, sob a forma de coalizão.

Com esse novo entendimento, tornou-se muito mais fácil colocar a sujeira debaixo do tapete, mantendo qualquer ficha "limpa", em ordem a que o mau gestor permaneça elegível, ainda que tenha cometido desvios e malversações. A consequência é clara e evidente: vê-se surgir mais um reduto - dos grandes - de impunidade dos agentes políticos que utilizem ilicitamente do dinheiro público. ${ }^{105}$

ou ao Tribunal de contas em função do cargo ocupado pelo administrador, e não da natureza das contas prestadas. (STF, RE n. 848.826/DF, Rel. Min. Luís Roberto Barroso, j. 17.08.2016).

105 COUTINHO, Doris de Miranda. Uma ideia falsa, porém clara e precisa. O Estado de S.Paulo, Blog Fausto Macedo. Disponível em: <http://politica.estadao.com.br/blogs/fausto-macedo/ uma-ideia-falsa-porem-clara-e-precisa/>. Acesso em: 25 jan. 2017. 
